\title{
Supplementary material for: A new terrestrial biosphere model with coupled carbon, nitrogen, and phosphorus cycles (QUINCY v1.0; revision 1610)
}

\author{
Tea Thum $^{1}$, Silvia Caldararu ${ }^{1}$, Jan Engel ${ }^{1}$, Melanie Kern ${ }^{1,2}$, Marleen Pallandt ${ }^{1,2}$, Lin Yu ${ }^{1}$, and \\ Sönke Zaehle ${ }^{1,3}$ \\ ${ }^{1}$ Max Planck Institute for Biogeochemistry, Hans-Knöll Str. 10, 07745 Jena, Germany \\ ${ }^{2}$ International Max Planck Research School (IMPRS) for Global Biogeochemical Cycles, Jena, Germany \\ ${ }^{3}$ Michael Stifel Center Jena for Data-driven and Simulation Science, Jena, Germany
}

Correspondence: Tea Thum (tthum@bgc-jena.mpg.de), Sönke Zaehle (szaehle@bgc-jena.mpg.de)

This Supplementary Material includes a detailed model description with equations. Section 1 summarises the general structure and vertical discretisation of vegetation and soil, and introduces general parameters (Tab 1). Section 2 describes the canopy processes, such as photosynthesis and stomatal coupling, with parameters in Tab. 2. Section 3 introduces vegetation growth, turnover and dynamics and the corresponding parameters are in Tab. 3. The soil biochemistry is described in Section 4, and its parameters are in Tab. 4. Section 5 describes the implementation of the isotope code, with parameters in Tab. 5. Section 6 describes the radiation scheme, surface energy balance and soil hydrology, with parameters described in Tab. 6. The PFT-specific parameters are listed in Tab. 7.

\section{General model structure and discretisation}

Each gridcell of the model is subdivided into nested tiles, each of which is occupied by one specific vegetation-type, representing a plant functional type (PFT). The number of tiles per gridcell is flexible, making it is easy to implement more/different PFTs in the future. In the model, vegetation is represented by an average individual composed of a range of structural pools (leaves, sapwood, heartwood, coarse roots, fine roots, and fruit), a fast overturning, respiring non-structural pool (labile), as well as a seasonal, non-respiring, and non-structural storage pool (reserve). Tree vegetation types are furthermore characterised by their height $(\mathrm{m})$, diameter $(\mathrm{m})$, and stand density $\left(\mathrm{m}^{-2}\right)$. Soil biogeochemistry is represented using five organic pools: metabolic (met), structural (str) and and woody (wl) litter, as well as fast (f) and slow (s) overturning soil organic matter. Each of these pools contains carbon $(\mathrm{C})$, nitrogen $(\mathrm{N})$ and phosphorus $(\mathrm{P})$, as well as ${ }^{13} \mathrm{C},{ }^{14} \mathrm{C}$, and ${ }^{15} \mathrm{~N}$. The unit of the pools is $\mathrm{mol} \mathrm{X} \mathrm{m}^{-2}$ for vegetation and $\mathrm{mol} \mathrm{X} \mathrm{m}^{-3}$ for soil biogeochemical pools, where $X$ represents any of these elements. In addition, the model represents the following soil biogeochemical pools $\left(\mathrm{NH}_{4}, \mathrm{NO}_{3}, \mathrm{NO}_{\mathrm{y}}, \mathrm{N}_{2} \mathrm{O}, \mathrm{N}_{2}\right.$, and $\left.\mathrm{PO}_{4}\right)$, with equivalent units.

The model operates on a half-hourly time-scale (denoted as $d t$ ). Vegetation processes are assumed to respond to these instantaneous conditions and associated fluxes with a process-specific lag time ( $\tau_{\text {mavg }}^{\text {process }}$, see Tab. 1$)$, representing a form of 
memory for instance in the calculation of allocation or vegetation dynamic responses. Where appropriate, the fluxes or pool sizes are calculated as running means with a time-averaging filter as

$$
\begin{aligned}
X_{\text {mavg }, \text { new }}^{\text {process }} & =X_{\text {mavg,old }}^{\text {process }} \times(1-\omega)+X_{\text {current }} \times \omega, \text { where } \\
\omega & =\frac{d t}{\tau_{\text {mavg }}^{\text {process }}}
\end{aligned}
$$

where $X_{\text {current }}$ is the instantaneous state or flux of interest, and $X_{\text {mavg,old }}^{\text {process }}$, as well as $X_{\text {mavg, new }}^{\text {process }}$ are the averaged values of the previous and current time step, respectively.

\subsection{Vertical discretisation}

The canopy is discretised into 10 layers (denoted by subscript $c l$ ), with exponentially increasing layer depth $\left(L A I_{c l}\right)$ to allow for a better resolution of canopy processes in areas of high light and nitrogen gradients. Total foliage $\mathrm{N}\left(N_{\text {leaf }}\right)$ is distributed to each canopy layer $c l$, following

$$
\begin{array}{r}
N_{\text {leaf }, c l}=N_{\text {leaf }, c l=1} \times e^{-k_{n} \times L A I_{c}}, \text { where } \\
N_{\text {leaf }, c l=1}=\frac{k_{n}}{1-e^{-k_{n} \times L A I}} N_{\text {leaf }}
\end{array}
$$

where $L A I_{c}$ is the cumulative leaf area above the centre-point of the canopy layer, and $L A I$ the total leaf area, such that less $\mathrm{N}$ is allocated to the lower, darker canopy layers, in accordance with observations of canopy $\mathrm{N}$ distribution (Niinemets et al., 15 1998).

All soil state-variables (temperature, moisture, texture, soil biogeochemical pools) and fluxes are discretised into 15 soil layers (denoted by subscript $(s l)$. Layer thickness increases exponentially with increasing layer depth up to a total depth of 9.5 $\mathrm{m}$, and with a minimum layer thickness for the top layer of $0.065 \mathrm{~m}$. Fine roots and coarse roots are assumed to be distributed in exponentially decreasing density along the soil profile according to

$$
\begin{array}{r}
X_{\text {root }, s l}=X_{\text {root }, s l=1} \times e^{-k_{\text {root_dist }} \times d e p t h_{s l}}, \text { where } \\
X_{\text {root }, s l=1}=\frac{k_{r d}}{1-e^{-k_{\text {root_dist }} \times \text { depthr }_{r}}} X_{\text {root }}
\end{array}
$$

where $k_{r d}$ is a PFT-specific parameter (see Tab. 7, Jackson et al. (1996)), depth $h_{s l}$ the depth of the soil layer's mid point, $d_{e p t} h_{r}$ the rooting depth, derived from site characteristics and $X_{\text {root }}$ the respective fine or coarse root mass. For clarity in the following, the subscript for canopy and soil layer is ignored if processes are treated similarly across layers. 


\section{Canopy processes}

\subsection{Canopy nitrogen allocation}

The leaf area index $(L A I)$ and canopy nitrogen content $\left(N_{\text {leaf }}\right)$ are dynamic properties of the model, as described in Section 3, and are discretised to canopy layers given by Eq. 2. $N_{l e a f, c l}$ is partitioned into photosynthetic and non-photosynthetic, or

5 structural, $\mathrm{N}$. The fraction of structural $\mathrm{N}\left(f N_{s t r u c, c l}\right)$ is calculated as a function of the total leaf $\mathrm{N}$ in the respective canopy layer:

$$
f N_{\text {struc }, c l}=k_{0}^{s t r u c}-k_{1}^{s t r u c} N_{l e a f, c l}
$$

where $k_{0}^{\text {struc }}$ is a PFT-specific parameter and $k_{1}^{\text {struc }}$ is an empirical constant.

The photosynthetic $\mathrm{N}$ is further separated into the fraction that is associated with Rubisco $\left(f N_{r u b}\right)$, electron transport $\left(f N_{e t}\right)$, chlorophyll $\left(f N_{c h l}\right)$ and in the case of C4 plants, a fourth fraction for PEP carboxylase $f N_{\text {pepc }}$.

The fraction of $\mathrm{N}$ in chlorophyll for each layer is calculated as decreasing with canopy depth:

$$
f N_{c h l}=\frac{k_{0}^{c h l}-k_{1}^{c h l} e^{-k_{f n}^{c h l} L A I_{c}}}{a_{c h l}^{n}},
$$

where $k_{0}^{c h l}, k_{1}^{c h l}$ and $k^{c h l}$ are empirical parameters, $a_{c h l}^{n}$ is the molecular $\mathrm{N}$ content of chlorophyll.

The values of $f N_{r u b}$ and $f N_{e t}$ are calculated assuming a fixed ratio of the $V_{c \max }$ and $J_{\max }$ photosynthetic parameters at $1525^{\circ} \mathrm{C}, r_{J 2 V}$, given the calculated values of the structural and photosynthetic fractions. The PEP carboxylase fraction, $f N_{p e p}$, is considered to be a constant.

\subsection{Leaf-level net photosynthesis}

The calculation of leaf-level photosynthesis is based on Kull and Kruijt (1998), extended for C4 photosynthesis according to Friend et al. (2009), and with the temperature response curves as described in Bernacchi et al. (2001). Unless stated otherwise, temperature sensitivities follow the form:

$$
f_{x}\left(T_{a i r}\right)=e^{E_{0}^{x}-E_{1}^{x} /\left(R \times T_{a i r}\right)}
$$

where $T_{\text {air }}$ is the air temperature $(\mathrm{K}), R$ is the universal gas constant $\left(\mathrm{Jmol}^{-1} \mathrm{~K}^{-1}\right)$, and the process-wise $E_{0}^{x}$ and $E_{1}^{x}$ are given in Table 2.

Photosynthesis and stomatal conductance are calculated for the mid-points of each canopy layer and light-quality class (sunlit and shaded; as defined in Sect. 6.1). For clarity, the subscript ${ }_{c l}$ is omitted in this section.

In light-saturated conditions, gross photosynthesis $\left(A_{g}\right)$ in $\mathrm{C} 3$ plants is calculated as the minimum of two potential rates, The electron-transport capacity limited carboxylation $\left(A_{j}\right)$ and the Rubisco-limited rate of photosynthesis $\left(A_{v}\right) . A_{j}$ is given by 


$$
\begin{gathered}
A_{j}=m_{1} \times J_{\text {max }}, \text { where } \\
m_{1}=\frac{c_{i}}{c_{i}+2 \times \Gamma^{*}}, \\
J_{\text {max }}=n_{1} \times N_{\text {leaf }},
\end{gathered}
$$

5

$$
n_{1}=g_{\text {jmax }}\left(T_{\text {air }}\right) \times \beta_{\text {soil }}^{\text {ps }} \times \beta_{\text {sinklim }}^{\text {ps }} \times \beta_{\text {soa }}^{\text {ps }} \times j_{\text {max }}^{n} \times f N_{\text {et }}
$$

where $c_{i}$ is the intercellular partial pressure of $\mathrm{CO}_{2}$ ( $\mathrm{Pa}$, Eq. 17), and $\Gamma^{*}$ is the $\mathrm{CO}_{2}$ compensation point in the absence of dark respiration. $\beta_{\text {sinklim }}^{\text {ps }}$ is a signal to reduce photosynthesis in the case of $\mathrm{C}$ sink limitation (Eq. 43) and $\beta_{\text {soa }}^{p s}$ is accounting for the effect of low-temperature acclimation in the evergreen species (Eq. 46). Excessive soil moisture constraints (as discussed in Rogers et al. (2017)) are assumed to reduce light-saturated photosynthetic activity by:

$10 \beta_{\text {soil }}^{\text {ps }}=1-\frac{\Psi_{\text {soil }}}{\Psi_{\text {leaf }}^{\text {min }}}$,

where $\Psi_{\text {soil }}$ is the soil water potential in the root zone (Eq. 112) and $\Psi_{\text {leaf }}^{\min }$ is the PFT-specific minimum leaf water potential. The temperature sensitivity of electron transport is assumed to follow the bell-shaped form described by June et al. (2004), where $T_{j \max }^{o p t}$ is the optimum temperature for $J_{\max }$ according to Friend (2010), as follows:

$g_{\text {jmax }}\left(T_{\text {air }}\right)=e^{-\left(\frac{T_{a i r}-\bar{T}_{j \max }^{\text {opt }}}{T_{\Omega}}\right)^{2}}$,

$$
T_{j \max }^{o p t}=k 0_{j \max }^{\text {topt }}+k 1_{j \max }^{\text {topt }} \times T_{\text {air }} ; T_{j \max , \min }^{o p t}<T_{j \max }^{o p t} \leq T_{j \max , \max }^{o p t},
$$

where $T_{\Omega}$ is a PFT-specific parameter, $k 0_{\text {jmax }}^{\text {topt }}$ and $k 1_{\text {jmax }}^{\text {topt }}$ are parameters, $T_{\text {air }}$ is the air temperature, and $\bar{T}_{\text {jmax }}^{\text {opt }}$ in Eq. 9 is the mean of the daytime $T_{j \max }^{o p t}$ over the past few days $\left(\tau_{\operatorname{mavg}}^{j \max }\right)$, thereby accounting for temperature acclimation of photosynthesis as in Friend (2010).

$A_{v}$ is given by

20

$$
\begin{aligned}
A_{v}= & m_{2} \times V_{\text {cmax }}, \text { where } \\
& m_{2}=\frac{c_{i}}{c_{i}+k_{c}\left(1+O_{i} / k_{o}\right)}, \\
& V_{\text {cmax }}=n_{2} \times N_{\text {leaf }} \\
& n_{2}=f_{\text {vcmax }}\left(T_{\text {air }}\right) \times \beta_{\text {soil }}^{\text {ps }} \times \beta_{\text {sinklim }}^{\text {ps }} \times \beta_{\text {soa }}^{\text {ps }} \times v_{\text {cmax }}^{n} \times f N_{\text {rub }}
\end{aligned}
$$

where $O_{i}$ is the intercellular partial pressure of $\mathrm{O}_{2}$, and $k_{c}$ and $k_{o}$ are the Michaelis-Menten constants for $\mathrm{CO}_{2}$ and $\mathrm{O}_{2}$ 25 respectively, derived $E_{0}^{k c}, E_{1}^{k c}$, or $E_{0}^{k o}, E_{0}^{k o}$ using Eq. 6.

The $\mathrm{N}$-specific light-saturated rate of $\mathrm{C} 3$ photosynthesis can then be calculated as:

$$
m_{\text {sat }}=\min \left(n_{1} \times m_{1}, n_{2} \times m_{2}\right)
$$


Friend et al. (2009) adjusted the scheme by Kull and Kruijt (1998) using the Collatz formulation of C4 photosynthesis Collatz et al. (1992). The simplified assumption is that $A_{j}$ and $A_{v}$ can be calculated as above, but at saturating $c_{i}\left(c_{i, \max }\right)$. Bundle-sheath transport limitation $\left(A_{p}\right)$ is then further limiting $\mathrm{C} 4$ photosynthesis, given by

$A_{p}=V_{\text {pmax }} \times m_{3}$, where

5

$$
\begin{aligned}
& V_{\text {pmax }}=n_{3} \times N_{\text {leaf }} \\
& n_{3}=g_{\text {pepc }}\left(T_{\text {air }}\right) \times v_{\text {pepc }}^{n} \times f N_{\text {pepc }}, \\
& m_{3}=\frac{c_{i}}{p},
\end{aligned}
$$

where the temperature response is

$g_{\text {pepc }}\left(T_{\text {air }}\right)=2^{\left(T_{\text {air }}-T_{\text {ref }}^{\text {pepc }}\right) / T_{\text {base }}^{\text {pepc }}}$

The N-specific light-saturated rate of $\mathrm{C} 4$ photosynthesis can be calculated as

$m_{\text {sat }}=\min \left(n_{1} \times m_{1}, n_{2} \times m_{2}, n_{3} \times m_{3}\right)$

The light-harvesting limited rate of photosynthesis $\left(A_{h}\right)$ can be written as

$$
\begin{aligned}
A_{h}= & m_{1} \times \alpha_{i} \times P P F D_{a}, \\
& P P F D_{a}=P P F D_{0}\left(1-e^{-k_{a} \times C_{c h l}}\right), \text { where }
\end{aligned}
$$

$$
C_{c h l}=a_{c h l}^{n} \times f N_{c h l} \times N_{\text {leaf }}
$$

where $\alpha_{i}$ is the intrinsic quantum efficiency for $\mathrm{CO}_{2}$ uptake, $P P F D_{0}$ is the photosynthetic photon flux density (PPFD) penetrating sunlit or shaded foliage, converted from the adsorbed radiation of the canopy layer (Eq. 102), and $k_{a}$ as well as $a_{c h l}^{n}$ are parameters specified in Table 2.

As Kull and Kruijt (1998) show, this system of equations (Eq. 7-15) can be solved to yield gross photosynthesis $\left(A_{g}\right)$ for one canopy layer and light-class as:

$$
\begin{aligned}
A_{g}=\left(1-\frac{\Gamma^{*}}{c_{i}}\right)\left[m_{\text {sat }}\right. & N_{\text {sat }}+\alpha_{i} \operatorname{PPF} D_{a}\left(e^{-k_{a} \times a_{\text {chl }}^{n} \times f N_{\text {chl }} \times N_{\text {sat }}}-e^{-k_{a} \times a_{\text {chl }}^{n} \times f N_{\text {chl }} \times N_{\text {leaf }}}\right), \text { where } \\
N_{\text {sat }} & =0: N_{\text {lim }}<0 \\
N_{\text {sat }} & =N_{\text {lim }}: N_{\text {lim }}<N_{\text {leaf }} \\
N_{\text {sat }} & =N_{\text {leaf }}: N_{\text {lim }} \geq N_{\text {leaf }}, \text { and } \\
N_{\text {lim }} & =-\frac{\ln \left(m_{\text {sat }} /\left[\alpha_{i} \times P P F D \times k_{a} \times a_{c h l}^{n} \times f N_{\text {chl }} \times m_{1}\right]\right)}{k_{a} \times a_{c h l}^{n} \times f N_{c h l}}
\end{aligned}
$$




\subsection{Stomatal coupling}

The combination of leaf-level net photosynthesis $\left(A_{n, c l}\right)$, stomatal conductance $\left(g_{s, c l}\right)$, and leaf internal $\mathrm{CO}_{2}$ concentration $\left(c_{i, c l}\right)$ satisfying Eq. 17 is sought iteratively for each canopy layer:

$$
A_{n}=\left(A_{g, \text { sunlit }} \times f_{\text {sunlit }}+A_{g, \text { shaded }} \times\left(1-f_{\text {sunlit }}\right)\right)-R_{l}
$$

$5 g_{s}=\left[g_{0}+g_{1} \frac{A_{n} \beta_{\text {air }} \beta_{\text {soil }}^{g s}}{c_{a}}\right] \times R \times T_{\text {air }} / p$

$c_{i}=c_{1} \times c_{a}-c_{2} \times A_{n} \times\left(\frac{D_{a i r}^{w v 2 c o 2}}{g_{s}}+\frac{D_{t u r b}^{w v 2 c o 2}}{g_{a}}\right) \times R \times T_{a i r}$

where $f_{\text {sunlit }}$ is the fraction of sunlit leaves in a canopy layer (see Eq. 101), $R_{l}$ is the maintenance respiration of leaves (see Sect. 3.2), $g_{0}$ and $g_{1}$ are PFT-specific parameters, $R$ is the molar gas constant, $T_{\text {air }}$ is air temperature (K), $p$ air pressure (Pa), $c_{1}$ converts $\mathrm{CO}_{2}$ concentration from ppm to $\mathrm{Pa}, c_{2}$ converts $\mu$ molm ${ }^{-2} \mathrm{~s}^{-1}$ to molm ${ }^{-2} \mathrm{~S}^{-1}, g_{a}$ is the aerodynamic conductance, and the $D$ 's are the diffusion coefficient corrections for $\mathrm{CO}_{2}$ and water (Bonan, 2015).

$\beta_{\text {air }}$ is taken as relative humidity (Ball et al., 1987; Knauer et al., 2015) and $\beta_{\text {soil }}^{g s}$ is the stomatal response to soil moisture, described by:

$$
\beta_{\text {soil }}^{\text {gs }}=1-\frac{\Psi_{\text {soil }}}{\Psi_{\text {leaf }}^{\text {min }}}
$$

where $\Psi_{\text {soil }}$ is the soil water potential in the root zone (Eq. 112) and $\Psi_{\text {leaf }}^{\min }$ is the PFT-specific minimum leaf water potential.

\subsection{Canopy integration}

Canopy-level fluxes are derived by summing the product of layer-level fluxes or state-variables and the depth of the layer

$F=\sum_{c l=1}^{n c a n o p y} F_{c l} \times L A I_{c l}$,

where $F$ is the canopy-level equivalent of a leaf-level variable $F_{c l}$ (per unit leaf-area), such as gross photosynthesis $\left(A_{g}\right)$, net photosynthesis $\left(A_{n}\right)$, and leaf-level stomatal conductance $\left(g_{s}\right)$, (see Sect. ?? and 2.3) and $L A I_{c l}$ is the leaf area index of the canopy layer. The resulting canopy net assimilation $A_{g}$ is used as input to the vegetation model (Eq. 20), the canopy conductance $\left(G_{s}\right)$ is used for the calculation of ecosystem transpiration (Eq. 118).

\section{Vegetation growth, turnover and dynamics}

\subsection{Labile pool dynamics}

The growth of a plant is dependent on the partitioning of its labile resource to new tissue growth, storage production, as well as - in the case of $\mathrm{C}$ - respiration for maintenance and resource uptake: 


$$
\begin{aligned}
& \frac{d C_{\text {labile }}}{d t}=A_{g}+\Delta S_{C}-R_{m}-R_{r}-\left(1+f_{\text {resp }, \text { growth }}\right) \times G_{C} \\
& \frac{d N_{\text {labile }}}{d t}=U_{\text {root }, N}+\Delta S_{N}-G_{N} \\
& \frac{d P_{\text {labile }}}{d t}=U_{\text {root }, P}+\Delta S_{P}-G_{P}
\end{aligned}
$$

where $R_{m}$ is maintenance respiration, $R_{r}$ is resource uptake respiration (for both see Sect. 3.2), $\Delta S_{X}$ is the net exchange 5 between the labile and reserve pool (Sect. 3.6), $f_{\text {resp, growth }}$ is the constant fraction of respiration associated with growth, $G_{X}$ are the growth rates to build new tissues, $U_{\text {root }, X}$ are nutrient rates of root uptake.

\subsection{Maintenance respiration}

Maintenance respiration for every vegetation pool $(i)$ is estimated from its $\mathrm{N}$ content $\left(N_{i}\right)$ as

$$
R_{m, i}=f_{\text {temp }} \times f_{\text {resp }, \text { maint }}^{i} \times N_{i}
$$

where $f_{\text {resp,maint }}^{i}$ is the maintenance respiration per unit $\mathrm{N}$, which differs between woody and non-woody pools, and $f_{\text {temp }}$ is the instantaneous temperature response of respiration (Lloyd and Taylor (1994))

$$
f_{\text {temp }}=e^{t_{k 1}\left(\frac{1}{t_{k 2}}-\frac{1}{T-t_{k 3}}\right)}
$$

where $t_{k 1}, t_{k 2}$ and $t_{k 3}$ are temperature sensitivity parameters and $T$ is the instantaneous air or soil temperature for aboveand belowground tissues, respectively. Following Atkin et al. (2014), the basal respiration rate acclimates to temperature

$15 f_{\text {maint_rate }}=f_{\text {maint_rate_ref }} 10^{f_{\text {resp_acclim }}\left(T_{\text {acclim }}-T_{\text {acclim }, \text { ref }}\right)}$

where $f_{\text {maint_rate,ref }}$ is the $\mathrm{N}$-specific maintenance respiration rate at the temperature $T_{\text {acclim,ref }}, f_{\text {resp_acclim }}$ is the slope of the temperature acclimation and $T_{\text {acclim }}$ is the running average of air or soil temperature $\left(\tau_{\text {mavg }}^{\text {resp }}\right)$, respectively.

Resource uptake respiration for nutrients is given by specific costs (cost $t_{i}$, Zerihun et al. (1998)) to transform nutrients from mineral sources $(i)$ into organic material and the actual plants uptake $U_{\text {plant }, i}(4.5)$ as

$20 R_{r, i}=$ cost $_{i} \times U_{\text {plant }, i}$

where $i$ is either $\mathrm{NH}_{4}$ or $\mathrm{NO}_{3}$.

\subsection{Growth}

The potential, source-limited growth rate $\left(G_{X}^{*}\right)$ is given by the product of the maximum turnover rate of the labile pool $\left(1 / \tau_{\text {labile }}\right)$ and the labile pool size $\left(X_{\text {labile }}\right)$. Three sink limitation processes operate, which control the down-regulation of 25 this potential growth rate to the actual growth rates $\left(G_{X}\right)$ : 
- the temperature and moisture sensitivity of the meristem (Eq. 25);

- the requirement for maintenance respiration (Eq. 21), which takes priority over new growth; and

- the co-limitation of growth by the nutrients required to grow specific pools (Eq. 28).

The meteorological/environmental control on the meristem mechanism is represented by a reduction of the maximum 5 turnover rate at low temperatures and low soil moisture conditions.

$k_{\text {labile }}^{*}=\frac{1}{\tau_{\text {labile }}} \times e^{-\left(\lambda_{\text {temp }}^{\text {labile }} \times T_{\text {air }}\right)^{k_{\text {temp }}^{\text {labile }}}} \times e^{-\left(\lambda_{\Theta}^{\text {labile }} \times \Theta\right)^{k_{\Theta}^{l a b i l e}}}$

where $T_{a i r}$ is air temperature in degrees Celsius, $\Theta$ is the fractional soil moisture content (Eq. 111), and the $\lambda$ and $k$ are parameters. $k_{\text {labile }}^{*}$ is set to zero outside the growing season (see Sect. 3.8).

Respiration is assumed to have priority over growth. However, under severe $\mathrm{C}$ deficit, the meristem activity also downregulates maintenance and resource uptake respiration. To ensure that carbon growth $\left(G_{C}\right)$ does not exceed the size of the labile carbon pool, the turnover rate of the labile pool to growth is corrected by the current respiration rate, and constrained to positive solutions:

$G_{C}^{*}=k_{\text {labile }}^{*} \times C_{\text {labile }} \times d t-R_{m}-R_{r} ; G_{C}^{*} \geq 0$

Given $G_{C}^{*}$, and the stoichiometric requirements for biomass growth $\left(r e q_{N C}^{\text {growth }}\right.$, and $r e q_{P N}^{\text {growth }}$, respectively):

$15 r e q_{X Y}^{\text {growth }}=\sum_{i}^{\text {pools }} f_{\text {alloc }}^{i} \times \frac{X_{i}}{Y_{i}}$

where $f_{\text {alloc }}^{i}$ are the allocation fractions (Sect. 3.4) to each pool $i$, and $\frac{X_{i}}{Y_{i}}$ are the target stoichiometries of C:N:P (Sect. 3.5) of the leaf, fine root, coarse root, sapwood, and fruits pools. The actual growth rates can be calculated as

$$
\begin{aligned}
G_{P}=r e q_{N: P}^{\text {growth }} \times G_{N}=r e q_{P: N}^{\text {growth }} \times r e q_{N: C}^{\text {growth }} \times G_{C} \\
G_{C} \leq G_{C}^{*} \\
G_{N} \leq \frac{k_{\text {labile }}^{\text {nut }}}{\tau_{\text {labile }}} \times N_{\text {labile }} \times d t \\
G_{P} \leq \frac{\left(k_{\text {labile }}^{\text {nut }}\right)^{2}}{\tau_{\text {labile }}} \times P_{\text {labile }} \times d t,
\end{aligned}
$$

Note that only the minimum of the three rates in eq. 28a can actually be realised. The other two growth rates are adjusted, implying a relative accumulation of these elements in the labile pool. The use of $k_{\text {labile }}^{n u t}$ implies a stronger mobilisation capacity for nutrients than for carbon growth. The assumption behind this is that the temperature and moisture control of the meristem 
is already accounted for by $G_{C}$, and that the plant is able to mobilise the required nutrients from the labile pool to support this growth.

Outside the growing season, all growth fluxes are set to zero (see Sect. 3.8).

\subsection{Growth partitioning}

5 The labile pool partitioned to growth is first split into reproductive (fruit pool) and structural (leaves, fine and coarse roots and sap wood) growth. The latter is then further subdivided following a functional balance relationship between the structural pools (Zaehle and Friend, 2010).

The fraction of carbon growth allocated to fruit depends on the ability of the plant to build reserves ( $\Delta S_{C}$, see Sect. 3.6), implying that fruit growth is suppressed during phases of rapid leaf growth (beginning of the growing season), as well as periods of C starvation (e.g. severe drought).

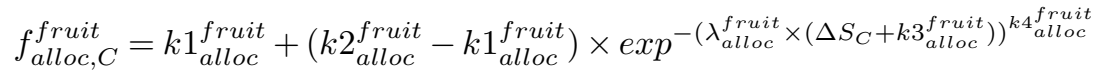

where the maximum fraction of allocation to fruits $\left(k 2_{\text {alloc }}^{\text {fruit }}\right)$ is a PFT-specific parameter. The allocation of the remaining growth $\left(\left(1-f_{\text {alloc, } C}^{\text {fruit }}\right) \times G_{C}\right)$ to the structural pools leaves, fine root, coarse roots, and sapwood follows a set of following allometric relationships (Zaehle and Friend, 2010).

For both trees and grasses, fine root and leaves are assumed to be in homeostatic balance described as

$C_{\text {leaf }}=f_{N|P| H_{2} 0}^{\text {ltor }} \times k_{\text {rtos }} \times \frac{C_{\text {leaf }}}{C_{\text {sap_wood }}} \times C_{\text {fine_root }}$

where $k_{r t o s}$ is a PFT-specific parameter and $f^{\text {ltor }}$ is a function describing the response of the leaf to root ratio to nutrient and water limitation. It is calculated as the minimum of three functions describing N, P and water limitation respectively, calculated as:

$20 f^{\text {ltor }}=\min \left(\frac{N_{\text {labile }} / C_{\text {labile }}}{r e q_{N C}^{\text {growth }}}, \frac{P_{\text {labile }} / N_{\text {labile }}}{r e q_{P N}^{\text {growth }}}, \frac{W_{\text {soil }, \text { root }}}{W_{\text {soil }, \text { crit }}^{\text {alloc }}}\right)$

$X_{\text {labile }}$ refers to the content of the respective element in the labile pool and $r e q_{N C}^{\text {growth }}$ and $r e q_{P N}^{g r o w t h}$ are the N:C and P:N ratios required for growth, respectively (see eqn. 27). For the water limited allocation, $W_{\text {soil } \text {,crit }}^{\text {alloc }}$ is the critical level of soil moisture below which root allocation increases and $W_{\text {soil,root }}$ is calculated as the ratio between the current water content in the root zone and the water content in the root zone at field capacity.

In grasses, halms are assumed to be a proportion of leaf mass, and no height restrictions apply.

$C_{\text {leaf }}=k_{h t o l} \times C_{\text {sap_wood }}$ 
In trees and shrubs, leaf and woody biomass are linked through the pipe-model hypothesis (requiring a constant ratio of leaf area, $L A$, to sapwood area, $S A$ )

$C_{\text {leaf }}=\frac{k_{\text {latosa }} \times C_{\text {sap_wood }}}{\text { sla } \times \rho_{\text {wood }} \times H}<=>L A=k_{\text {latosa }} \times S A$,

where sla, $k_{\text {latosa }}$, and $\rho_{\text {wood }}$ are the PFT-specific specific leaf area, leaf to sapwood area ratio, and wood density, respec-

5 tively. $H$ is the mean forest canopy height calculated as:

$H=k 1_{\text {allom }} \times D^{k 2_{\text {allom }}}$,

where the diameter at breast height $(D)$ is determined from woody biomass, assuming that the entire trunk is a cylinder. As an extension to the pipe-model theory below-ground, coarse root biomass is assumed to be proportional to sap wood mass:

$C_{\text {coarse_root }}=k_{\text {ctos }} \times C_{\text {sap_wood }}$

where $k_{c t o s}$ is a PFT-specific parameters.

\subsection{Tissue stoichiometry}

Following Meyerholt and Zaehle (2015), C:N:P stoichiometry for slow-overturning structural tissues (sap wood, coarse roots) as well as fruits, is assumed to be time-invariant and modelled as dependent on the PFT-specific mean foliar stoichiometry $\left(\chi_{\text {leaf }}^{C: N}\right.$, and $\chi_{\text {leaf }}^{N: P}$ ) and set ratios (see Table 3 ). Heartwood stoichiometry differs from sapwood stoichiometry because a fraction of the nutrients are retranslocated $\left(k_{\text {resorb }}^{\text {wood }}\right)$ to the labile pool upon heartwood formation.

Following Zaehle and Friend (2010), the C:N and N:P ratios of leaves are varied in response to the nutrient demand and supply so that:

$\chi_{\text {leaf } \mid t+1}^{X: Y}=\chi_{\text {leaf }}^{X: Y} \times\left(1+\delta_{\text {leaf }}^{\chi} \times \Gamma_{X Y}\right)$

where $\chi_{\text {leaf }}^{X: Y}$ denotes either the C:N or N:P ratio of the leaves, $\delta_{\text {leaf }}^{\chi}$ is a parameter denoting the maximum amount that leaf nutrients can change per timestep and $\Gamma_{X: Y}$ heuristically accounts for limits to the plasticity of foliar stoichiometry as:

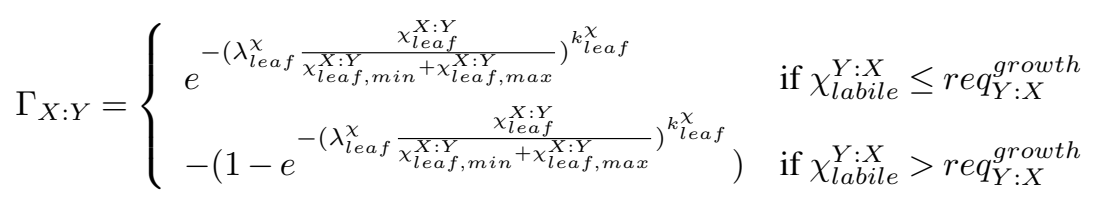

In the above, $\chi_{\text {leaf,min }}^{X: Y}$ and $\chi_{\text {leaf,max }}^{X: Y}$ are PFT-specific parameters. The condition refers to the relationship between the nutrients available for growth in the labile pool and the nutrients required for growth (Eq. 27), averaged at the time-scale of $\tau_{\text {mavg }}^{\chi}$. The stoichiometric ratios of the fine roots vary proportionally to those of the leaves, whereas the stoichiometry of wood is assumed time-invariant (Meyerholt and Zaehle, 2015). The stoichiometry of the labile and reserve pools are prognostic properties, as described in Sect. 3.6. 


\subsection{Long-term reserve dynamics}

The target leaf carbon pool $\left(C_{\text {leaf }}^{\text {target }}\right)$ is determined by the current allometry, and corresponds to the leaf area index implied by current sapwood area.

The target labile carbon pool size buffers short term fluctuations in GPP, and is assumed to correspond to the maximum of

5 the cumulated GPP or $R_{m}$ over the turnover time of the labile pool, while the target of the labile nitrogen and phosphorus pool corresponds to the average stoichiometric growth requirement over the turnover time of the labile pool:

$$
\begin{aligned}
C_{\text {labile }}^{\text {target }} & =\max \left(\int_{t=-\tau_{\text {labile }}^{0}}^{t=0} G P P \times d t, \int_{t=-\tau_{\text {labile }}^{0}}^{t=0} R_{m} \times d t\right) \\
N_{\text {labile }}^{\text {target }} & =r e q_{N C}^{\text {growth }} \times C_{\text {labile }}^{\text {target }} \\
P_{\text {labile }}^{\text {target }} & =r e q_{P N}^{\text {growth }} \times N_{\text {labile }}^{\text {target }}
\end{aligned}
$$

The target size of the reserve pool depends on the $\mathrm{C}$ required to replace the annual growth of leaves and fine roots. It is scaled by a PFT-specific constant as a measure of risk avoidance $\left(k_{\text {reserve }}^{\text {target }}\right)$, with larger values indicating a preference for storage over growth.

$$
\begin{gathered}
C_{\text {reserve }}^{\text {target }}=\min \left(k_{\text {reserve }} \times\left(1+f_{\text {resp }, \text { growth }}\right) \times \frac{L A I^{\text {target }}}{\text { sla }}, \sum_{i=l, f, s} f_{\text {reserve,max }, i} \times C_{i}\right), \text { where } \\
k_{\text {store }}=k_{\text {reserve }}^{\text {target }} \times\left(\min \left(1, \frac{1}{\tau_{\text {leaf }}}\right)+\frac{1}{\tau_{\text {fine_root }} \times R_{\text {leaf:fine_root }}}\right)
\end{gathered}
$$

where $L A I^{\text {target }}$ is the target leaf area index, which is constrained to values below $L A I_{\text {max }}^{\text {target }}$ (see Sect. 3.4) and sla the PFTspecific specific leaf area, $\tau_{\text {leaf }}$ and $\tau_{\text {fine_root }}$ are the PFT-specific turnover times of foliage and fine roots, and $R_{\text {leaf }}$ : fine_root is the leaf to root ratio (Eq. 31) averaged over the lifetime of the fine roots $\left(\tau_{\text {mavg }}^{\text {root }}\right.$ ). The $\mathrm{N}$ and $\mathrm{P}$ target pools are defined in an equivalent manner, respecting the current target stoichiometry of leaves and fine roots (Sect. 3.5).

The net exchange between the labile and reserve pool is calculated as

$$
\begin{gathered}
\Delta S_{X}=\frac{1}{\tau_{\text {labile }}} \times\left(\Phi_{\text {maint }}^{X} \times X_{\text {reserve }}-\Phi_{\text {store }}^{X} \times X_{\text {labile }}\right) \times d t ; \text { with } \\
\Phi_{\text {maint }}^{X}=e^{-\left(\lambda_{\text {maint }}^{\Phi} \times \frac{X_{\text {labile }}}{X_{\text {labiet }}^{t a b}}\right)_{\text {maint }}^{\Phi}}, \text { and } \\
\Phi_{\text {store }}^{X}=1-e^{-\left(\lambda_{\text {store }}^{\Phi} \times \frac{X_{\text {reserve }}}{\left.X_{\text {reserve }}^{\text {tale }}\right)^{k_{\text {store }}}}\right.}
\end{gathered}
$$

where $\lambda_{\text {maint }}^{\Phi}, k_{\text {maint }}^{\Phi}, \lambda_{\text {store }}^{\Phi}$, and $k_{\text {store }}^{\Phi}$ are parameters of a Weibull-type function. Under conditions of severe resource stress (i.e. low labile pool size corresponding to its target size), the build up of reserves, is reduced according to

$$
\Phi_{\text {store }}^{X}=\frac{1-\Phi_{\text {maint }}^{X}}{1-k_{\Phi, \text { inter }}} \Phi_{\text {store }}^{X} \text { if } \Phi_{\text {maint }}^{X}>k_{\Phi, \text { inter }}
$$


where $k_{\Phi, \text { inter }}$ is a parameter. To support leaf and fine-root growth at the beginning of the growing season, $\Delta S_{X}$ is further modified by the phenological pull $\left(\Phi_{\text {phen }}^{X}\right)$ during the growing season as follows:

$$
\begin{gathered}
\Delta S_{X}=\Delta S_{X}+k_{\text {labile }}^{*} \times \Phi_{\text {phen }}^{X} \times X_{\text {reserve }} \times d t, \text { with } \\
\Phi_{\text {phen }}^{X}=e^{-\left(\lambda_{\text {phen }}^{\Phi} \times \frac{X_{\text {leaf }}}{\left.X_{\text {leaf }}^{\text {tart }}\right)^{k_{\text {phen }}^{\Phi}}}\right.}
\end{gathered}
$$

\subsection{Photosynthetic sink limitation}

In the case that the labile carbon pool exceeds its target size substantially because growth is limited by temperature, moisture, or because sufficient nutrients are lacking to allow growth (Eq. 28a), sink-limitation down-regulates photosynthetic activity so that:

$$
\begin{aligned}
\beta_{\text {sinklim }}^{p s} & =\beta_{\text {sinklim,min }}^{p s}+\left(1-\beta_{\text {sinklim,min }}^{p s}\right) \times e^{-\left(\lambda_{\text {sinklim }}^{p s} \times X\right)^{k_{\text {sinklim }}^{p s}}}, \text { where } \\
X & =\frac{C_{\text {labile }}-C_{\text {labile }}^{\text {target }}}{C_{\text {labile }}^{\text {target }}}
\end{aligned}
$$

Here, $\beta_{\text {sinklim,min }}, \lambda_{\text {sinklim }}^{\text {ps }}$ and $k_{\text {sinklim }}^{\text {ps }}$ are parameters (see Table 3) and $C_{\text {labile }}^{\text {target }}$ is the target value for the labile pool (Eq. 38).

In addition, if the $\mathrm{C}: \mathrm{N}$ or $\mathrm{N}: \mathrm{P}$ ratios of the labile pool exceed those of the target labile pool, the sink limitation factor is further modified as a function of the stoichiometric ratio of the labile pool and that of the labile target as:

$$
\begin{aligned}
& \beta_{\text {sinklim }}^{\text {ps }}=\beta_{\text {sinklim }}^{p s} \times \min \left(1, \frac{\chi_{\text {labile }}^{N: C}}{k_{\text {sinklim }}^{C N P} \times \chi_{\text {labile,target }}^{N: C}}, \frac{\chi_{\text {labile }}^{P: N}}{k_{\text {sinklim }}^{C N P} \times \chi_{\text {labile,target }}^{P: N}}\right) \\
& \text { where } k_{\text {sinklim }}^{C N P} \text { is a parameter. }
\end{aligned}
$$

\subsection{Phenology}

The phenology of vegetation, describing the seasonal development of foliage biomass, is simulated prognostically given the ability of the plant to grow new tissues, which depends on the size and turnover of the meristems (Eq. 28), as well as the fractional allocation of growth to plant organs (see Sect. 3.3). The start and end of the the growing season are determined by meteorological triggers and soil moisture, with plant growth set to zero outside the growing season (Eq. 28). The meteorological variables determining these phenological triggers are averaged over $\tau_{\text {mavg }}^{\text {phen }}$, to smooth out the effect of day-to-day climate variability. While the beginning and ending mark the start and end of tissue production, only the turnover of the leaves is directly affected by phenological triggers. The turnover of all other tissues is assumed to be constant (see Sect. 3.9). 
The model differentiates evergreen, cold deciduous, rain deciduous tree and shrub phenological strategies, as well as herbaceous perennial phenological strategies.

The growing season start for cold deciduous and herbaceous PFTs is described as a function of the accumulated growing degree days $\left(G D D_{a c c}\right)$ as:

$5 G D D_{a c c}>G D D_{r e q}^{\max } \times \exp ^{-k_{\text {dormance }}^{G D D} \times N D D}$, where

$$
\frac{G D D_{a c c}}{d t}=G D D_{a c c}+M A X\left(t_{a i r}-t_{\text {tair }}^{G D D}, 0.0\right)
$$

where $G D D_{a c c}$ denotes the current growing degree days above the temperature threshold $\left(t_{a i r}^{G D D}\right), N D D$ is the number of dormancy days, taken as days since the last growing season, and $k_{d o r m a n c e}^{G D D}$ is a PFT-specific parameter relating dormancy to the PFT-specific maximum growing degree days requirement $\left(G D D_{r e q}^{\max }\right)$ to account for the chilling requirements of the buds

10 (Krinner et al., 2005).

For rain deciduous phenology, the start of the growing season is triggered when the soil moisture stress factor $\left(\beta_{\text {soil }}^{g s}\right.$, see Eq. 18) is larger than a PFT-specific threshold $\left(\beta_{\text {soil }}^{f l u s h}\right)$. This criterion is also applied for herbaceous PFTs in addition to the $G D D$-criterion.

For the evergreen phenology, recovery of photosynthesis in spring is delayed according to the state of acclimation $(S)$ to air temperature, which reduces photosynthesis in spring until acclimation is reached (Mäkelä et al., 2004). $S$ is calculated as

$$
\frac{d S}{d t}=\frac{1}{\tau_{\text {soa }}}\left(T_{\text {air }}-S\right)
$$

where $\tau_{\text {soa }}$ is a time constant. The reduction factor for Rubisco- and electron transport limited photosynthesis $\left(\beta_{\text {soa }}\right)$ is calculated as

$20 \beta_{\text {soa }}=\frac{\left(S-T_{\min }^{\text {soa }}\right)}{\left(T_{\max }^{\text {soa }}-T_{\min }^{\text {soa }}\right)}$

where $T_{\text {min }}^{\text {soa }}$ and $T_{\text {max }}^{\text {soa }}$ are parameters and $\beta_{\text {soa }}$ is constrained to the range 0.1 and 1 .

The end of the growing season for cold deciduous and herbaceous PFTs is triggered by decreasing average air temperatures below a PFT-specific temperature threshold $\left(t_{a i r}^{s e n}\right)$. For raingreen and herbaceous PFTs the end of the growing season is triggered when the soil moisture stress factor $\left(\beta_{\text {soil }}^{\text {gs }}\right)$ becomes lower than a PFT-specific threshold $\left(\beta_{\text {soil }}^{\text {sen }}\right)$. In addition, herbaceous

25 PFTs end their growing season, once the weekly carbon balance $\left(G P P-R_{m}\right)$ becomes negative. Senescence is generally only introduced once the leaf age has become larger than a PFT-specific threshold (age $\left.\min _{\text {min }}^{\text {leaf }}\right)$. 


\subsection{Turnover}

The breakdown of leaf and fine-root nutrients occurs at the time-scale of $\tau_{\text {nut_recycle. }}$ The freed nutrients enter the labile pool and are replaced by new nutrients of the labile pool according to the current target $\mathrm{C}: \mathrm{N}: \mathrm{P}$ of the respective pool.

$$
\frac{X_{\text {pool }}}{d t}=\left(Y_{\text {pool }} \frac{X_{\text {pool }}^{\text {target }}}{Y_{\text {pool }}^{\text {target }}}-X_{\text {pool }}\right) \times 1 / \tau_{\text {nut_recycle }},
$$

where $X$ is either $\mathrm{N}$ or $\mathrm{P}$, and $Y \mathrm{C}$ or $\mathrm{N}$, respectively. The flux from the labile pool is limited by the turnover rate and size of the labile pool to ascertain that the latter cannot be exhausted.

The turnover time of most tissue types (fine and coarse roots, sapwood, and fruits) is assumed constant for each PFT ( $\tau_{\text {fine_root }}, \tau_{\text {coarse_root }}, \tau_{\text {sap_wood }}$, and $\tau_{\text {fruit }}$, respectively). While roots and fruit turn directly into litter, only a small fraction of sapwood $\left(f_{\text {sap_wood }}^{\text {branch }}\right)$ is turned to litter, assuming it is lost as branches $\left(\tau_{\text {branches }}\right)$, whereas the predominant fraction of sapwood turns into non-respiring hardwood at the timescale of $\tau_{\text {sap_wood. }}$. In evergreen trees, foliar turnover to litter is assumed to be constant $\left(\tau_{\text {leaves }}\right)$. For deciduous and herbaceous PFTs only minor turnover happens at $\tau_{\text {leaves }}$ during the growing season. At the end of the growing season (see Sect. 3.8), foliar turnover is set to a constant rate

$f_{\text {turn }}^{\text {leaf }}=\min \left(f_{\text {shed,max }} \times \frac{L A I^{\text {target }}}{L A I}, 1\right)$

Resorption of nutrients to the labile pool during litterfall is assumed to only occur during foliage turnover and heartwood

15 formation at a constant fraction $\left(k_{\text {resorb }}^{X}\right)$, so that:

$$
\begin{aligned}
& f l u x_{\text {pool } \rightarrow \text { litter }}^{X}=\left(1-k_{\text {resorb }}^{X}\right) \times \frac{X_{\text {pool }}}{\tau_{\text {pool }}} \times d t, \text { and } \\
& f_{\text {lux }}^{X} X x_{\text {ool } \rightarrow \text { labile }}=k_{\text {resorb }}^{X} \times \frac{X_{\text {pool }}}{\tau_{\text {pool }}} \times d t,
\end{aligned}
$$

where $f l u x_{\text {pool } \rightarrow \text { itter }}^{X}$ is the litterfall from any one pool, and $f l u x_{\text {pool } \rightarrow \text { labile }}^{X}$ the retranslocated flux into the labile pool.

\subsection{Vegetation dynamics}

20 To assess stand density, we define for tree functional types the crown area as:

$C A=k_{C A} \times D^{k_{r p}}$

where $k_{C A}$ and $k_{r p}$ are parameters, $D$ is the tree diameter at breast hight and $C A$ is constrained to be less then a maximum crown area $\left(C A_{\max }\right)$. Using stand-scale LAI, individuum density (dens $s_{i n d}$, see Eq. 58) and crown area, the LAI of an individual tree is defined $\left(L A I_{i n d}\right)$, which is used to calculated the foliage projective cover $(F P C)$ as:

$25 F P C=C A \times \operatorname{dens}_{\text {ind }}\left(1-e^{-k_{f p c} \times L A I_{\text {ind }}}\right)$ 
where $k_{f p c}$ is a paramter. To avoid strong seasonal cycles in foliage projective cover for the calculation of vegetation dynamics (Krinner et al., 2005; Zaehle and Friend, 2010), $L A I_{\text {ind }}$ is diagnosed from the sapwood area implied by the pipe-model (Eq. 33), implying that $F P C$ is essentially representing last year's maximum LAI. For grasses, the calculation of $F P C$ is not required and it is set to zero.

5 The establishment flux for a PFT is dependent on the size of the seed-bed pool and the average, PFT-specific seed-bed turnover time $\left(\tau_{\text {seed,est }}\right)$ :

$$
\text { flux }_{\text {est }, X}=f_{\text {dens }} \times f_{\text {temp }} \times f_{\text {moist }} \times \frac{X_{\text {seed_bed }}}{\tau_{\text {seed,est }}}
$$

where $f_{\text {temp }}$ and $f_{\text {moist }}$ represent limitations for establishment at low temperature and low moisture availability in the form of Weibull-functions with parameters $\lambda_{e s t}^{e n v}$ and $k_{e s t}^{e n v}$, where $e n v$ refers to either weekly air temperature $\left(T_{\text {air }}\right)$ or weekly top-soil moisture $\left(\Theta_{1}\right)$. Density dependency of establishment $\left(f_{\text {dens }}\right)$ is modelled as in Sitch et al. (2003):

$$
f_{\text {dens }}=M A X\left(F P C_{\max }-F P C, 0\right)
$$

Three types of mortality are considered as additive processes, growth-efficiency related mortality ( mort $_{\text {greff }}$ ), density dependent mortality $\left(\right.$ mort $\left._{d e n s}\right)$, and a PFT-specific background mortality, representing currently unaccounted for processes such as disturbance or grazing.

Growth-efficiency mortality, represents any kind of mortality associated with trees lacking the ability to defend themselves against stress (e.g. pathogens) and is calculated as:

$$
\begin{aligned}
& \text { mort }_{\text {greff }}=\frac{k 1_{\text {mort_greff }}}{1+k 2_{\text {mort_greff }} \times e f f_{\text {growth }}}, \text { where } \\
& \text { eff } f_{\text {growth }}=\frac{N P P-\sum \text { Turnover }_{i}}{L A I}
\end{aligned}
$$

where, as in Sitch et al. (2003), $k 1_{\text {mort_greff } f}$ and $k 2_{\text {mort_greff } f}$ are parameters and growth efficiency depends on net primary production minus tissue turnover (of all tissues $i$ ) per unit leaf area, calculated as running means over $\tau_{\text {mavg }}^{\text {dynics }}$.

Space constraints in tree populations (as for grasses $F P C$ is zero) are considered by constraining the foliage projected cover to a prescribed maximum $\left(F P C_{\max }\right)$ :

$$
\text { mort }_{\text {dens }}=M A X\left(F P C-F P C_{\max }, 0\right)
$$


Litterfall from vegetation dynamics is then the product of the current pool size and $f_{\text {mort }}$, scaled to the timestep of the model.

For trees, the appropriate number of individuals is also removed following mortality. This does not affect the size of trees, as woody biomass and stand density are modified proportionally. In total, the change in vegetation individual density following

$\frac{d e n s_{i n d}}{d t}=f_{m o r t} \times d e n s_{i n d}+\frac{f l u x_{e s t, C}}{k_{\text {seed }}}$

where $f l u x_{e s t, C}$ is the carbon flux defined by Eq. 53, and $k_{\text {seed }}$ is the PFT-specific seed size.

\section{Soil biogeochemistry}

The dynamics of the soil organic pools $(X)$ are described in general as:

$10 \frac{\partial}{\partial t} X_{m e t}=\sum\left(f_{v p \rightarrow m e t} F_{L_{v p}}\right)+f_{w l \rightarrow m e t} \eta_{w l \rightarrow m e t} \frac{X_{w l}}{\tau_{w l}}-\frac{X_{m e t}}{\tau_{m e t}}$

$\frac{\partial}{\partial t} X_{s t r}=\sum\left(f_{v p \rightarrow s t r} F_{L_{v p}}\right)+f_{w l \rightarrow s t r} \eta_{w l \rightarrow s t r} \frac{X_{w l}}{\tau_{w l}}-\frac{X_{s t r}}{\tau_{s t r}}$

$\frac{\partial}{\partial t} X_{w l}=\sum\left(f_{v p \rightarrow w l} F_{L_{v p}}\right)-\frac{X_{w l}}{\tau_{w l}}$

$\frac{\partial}{\partial t} X_{\text {fast }}=\eta_{l \rightarrow \text { fast }}\left(\frac{X_{\text {met }}}{\tau_{\text {met }}}+\frac{X_{\text {str }}}{\tau_{\text {str }}}\right)+\eta_{\text {slow } \rightarrow \text { fast }} \frac{X_{\text {slow }}}{\tau_{\text {slow }}}-\frac{X_{\text {fast }}}{\tau_{\text {fast }}}+\Phi_{l \rightarrow \text { fast }}+\Phi_{\text {slow } \rightarrow \text { fast }}+\frac{\partial}{\partial z}\left(D_{b} \frac{\partial X_{\text {fast }}}{\partial z}\right)$

$\frac{\partial}{\partial t} X_{\text {slow }}=\eta_{\text {fast } \rightarrow \text { slow }} \frac{X_{\text {fast }}}{\tau_{\text {fast }}}-\frac{X_{\text {slow }}}{\tau_{\text {slow }}}+\Phi_{\text {fast } \rightarrow \text { slow }}+\frac{\partial}{\partial z}\left(D_{b} \frac{\partial X_{\text {slow }}}{\partial z}\right)$

where $F_{L_{v p}}$ is the litterfall of the various plant tissue types, $f_{v p \rightarrow i}$ are the coefficients determining the partitioning of this litterfall to the litter pools (see Section 4.1), $\tau_{i}$ are temperature and moisture adjusted, nitrogen-limited turnover times of the respective pools (X; i = met, str, wl, fast, slow; see Section 4.3), $\eta_{i \rightarrow j}$ are the mass transfer from pool $i$ to $j$ (see Section 4.3), the $\Phi_{x}$ are the net mineralisation terms for $\mathrm{N}$ and $\mathrm{P}$, respectively, required to balance the carbon inflow to the fast and slow SOM pools and their respective C:N:P stoichiometry (see Sect. 4.3). The transfer of soil organic matter through bioturbation is represented with a prescribed diffusion constant (see Sect. 4.4).

The dynamics of the inorganic nitrogen pools are described as:

$$
\begin{aligned}
\frac{\partial}{\partial t} N H_{4} & =F_{d e p, N H_{4}}-U_{\text {plant }, N H_{4}}-\sum\left(\Phi_{i, N H_{4}}\right)-U_{n i t}-\frac{\partial v_{N H_{4}} N H_{4}}{\partial z} \\
\frac{\partial}{\partial t} N O_{3} & =F_{d e p, N O_{3}}+F_{n i t, N O 3}-U_{\text {plant }, N O_{3}}-\sum\left(\Phi_{i, N O_{3}}\right)-U_{\text {denit }}-\frac{\partial v_{N O_{3}} N O_{3}}{\partial z} \\
\frac{\partial}{\partial t} N O_{y} & =F_{n i t, N O_{y}}+F_{\text {denit }, N O_{y}}-E_{N O_{y}} \\
25 \frac{\partial}{\partial t} N_{2} O & =F_{n i t, N_{2} O}+F_{\text {denit }, N_{2} O}-E_{N_{2} O} \\
\frac{\partial}{\partial t} N_{2} & =F_{n i t, N_{2}}+F_{\text {denit }, N_{2}}-E_{N_{2}}
\end{aligned}
$$


where $U$ are the uptake rates of plants, or (de-)nitrifying bacteria, respectively (see Section 4.5 and 4.7, respectively); the $F_{d e p}$ are the atmospheric deposition fluxes; the $F_{n i t, i}$, and $F_{d e n i t, i}$ are the production of $\mathrm{NO}_{\mathrm{y}}, \mathrm{N}_{2} \mathrm{O}$ and $\mathrm{N}_{2}$ by nitrification and denitrification, respectively; , and $\frac{\partial v_{x} X}{\partial z}$ the vertical transport loss term given by the product of ion concentration and water mass flow between soil layers (see Sect. 6.3). Sorption of $\mathrm{NH}_{4}$ is not explicitly modelled, and is accounted for by a reduced 5 mobility in water $\left(f_{\text {leach }, \mathrm{NH}_{4}}\right)$.

The dynamics of the inorganic phosphorus pools are described as:

$$
\begin{aligned}
\frac{\partial}{\partial t} P O_{4} & =F_{\text {dep }, P O_{4}}+F_{\text {weath }, P O_{4}}+F_{\text {biomin }, P O_{4}}-U_{\text {plant }, P O_{4}}-F_{\text {adsorp }, P O_{4}}-\sum\left(\Phi_{i, P O_{4}}\right)-\frac{\partial v_{P O_{4}} P O_{4}}{\partial z} \\
\frac{\partial}{\partial t} P_{\text {lab }} & =F_{\text {adsorp }, P O_{4}}-F_{\text {desorp }, P O_{4}}+\frac{\partial}{\partial z}\left(D_{b} \frac{\partial P_{\text {lab }}}{\partial z}\right) \\
\frac{\partial}{\partial t} P_{\text {sorb }} & =F_{\text {desorp }, P O_{4}}-F_{\text {occlusion }, P O_{4}}+\frac{\partial}{\partial z}\left(D_{b} \frac{\partial P_{\text {sorb }}}{\partial z}\right) \\
\frac{\partial}{\partial t} P_{\text {ocl }} & =k_{\text {ocl }} P_{\text {sorb }}+\frac{\partial}{\partial z}\left(D_{b} \frac{\partial P_{\text {ocl }}}{\partial z}\right) \\
\frac{\partial}{\partial t} P_{\text {primary }} & =-F_{\text {weath }, P O_{4}}
\end{aligned}
$$

where $P_{l a b}, P_{\text {sorb }}, P_{\text {ocl }}$, and $P_{\text {primary }}$ are labile, absorbed, occluded, and primary P, respectively; the $F_{d e p, P O_{4}}, F_{w e a t h, P O_{4}}$, $F_{\text {biomin }, P O_{4}}, F_{a d s o r p, P O_{4}}$, and $F_{a d s o r p, P O_{4}}$ are the atmospheric deposition, weathering, fast adsorption, and phosphorus fluxes, respectively (see Section 4.8). All pools except the primary phosphorus pool are assumed to be affected by bioturbation (see Sect. 4.4).

\subsection{Partitioning of litterfall to litter pools}

Non-woody litterfall is partitioned to the metabolic and structural litter according to the CENTURY approach (Parton et al., 1993). Litter from labile and reserve pools is assumed to enter the metabolic pools, litter from sap- and heartwood enters the woody pool. The metabolic fraction of litterfall from each vegetation pool $\left(_{v p}\right.$, i.e. leaves, fine and coarse roots, fruits and seed-bed) is determined as:

$f_{v p \rightarrow m e t, C}=f_{m e t, \max , C}-k_{m e t, C} \times L C_{v p} \frac{C_{v p}}{N_{v p}}$

where $f_{v p \rightarrow m e t, C}$ is constrained to positive solutions, $f_{\operatorname{met}, \max , C}$ is the maximum fraction allocated to the metabolic pool, $k_{m e t, C}$ a factor relating the metabolic litter fraction to the lignin to nitrogen ratio, $L C_{v p}$ the tissue-specific fraction of the lignin content of that tissue type, and $\frac{C_{v p}}{N_{v p}}$ the C:N ratio of litterfall from that tissue. The lignin content is assumed constant for all but the leaf tissues. For the latter, an empirical dependency between lignin content and specific leaf-area (sla) is used (White et al., 2000).

$$
L C_{\text {leaf }}=L C_{\text {leaf }, \max }+k_{\text {leaf } 2 s l a} \times s l a
$$


The remainder of litterfall is allocated to the structural pool. For $\mathrm{N}$ and $\mathrm{P}$, the partitioning assumes that the relative proportions of $\mathrm{C}: \mathrm{N}$ and $\mathrm{N}: \mathrm{P}$ are preserved in the partitioning according to:

$f_{v p \rightarrow m e t, X}=\frac{1}{1+\frac{1-f_{v p \rightarrow m e t, C}}{k_{m e t, v p, X} \times f_{v p \rightarrow m e t, C}}}$

Woody decomposition is assumed to be a two-stage process. The first step implies physical destabilisation and a first level of

5 biochemical processing, which releases a constant fraction of carbon $\left(1-\eta_{C, w l \rightarrow m e t, s t r}\right)$ to heterotrophic respiration. During this step, a fraction of the nutrients $\left(1-\eta_{N} \mid \eta_{P}\right)$ is leached to the mineral phase to account for inefficiencies of the microbiota in mineral processing decomposing wood. The remainder is assumed to enter the metabolic and structural litter (Eq. 62 and 64).

\subsection{SOM and litter turnover rates}

The turnover times $\left(\tau_{i}^{\text {base }}\right)$ of the litter and SOM pools respond to soil temperature $\left(T_{\text {soil }}\right)$ and soil matrix potential $\left(\Psi_{\text {soil }}\right)$ as follows:

$$
\begin{aligned}
\tau_{i}^{*} & =\tau_{i}^{\text {base }} \times f\left(T_{\text {soil }}\right) \times g\left(\Psi_{\text {soil }}\right), \text { where } \\
f\left(T_{\text {soil }}\right) & =\frac{E_{d, \text { decomp }} \times e^{E_{a, \text { decomp }} \times T}}{E_{d, \text { decomp }}-E_{a, \text { decomp }} \times\left(1-e^{E_{d, \text { decomp }} \times T}\right)}, \text { with } \\
T & =\frac{T_{\text {soil }}-T_{\text {opt }, \text { decomp }}}{T_{\text {soil }} \times T_{\text {opt }, \text { decomp }} \times R}, \text { and } \\
g\left(\Psi_{\text {soil }}\right) & =1-\Psi_{\text {soil }} / \Psi_{\text {dec }, \text { min }}
\end{aligned}
$$

\subsection{SOM formation}

Matter entering the fast and slow SOM pool (Eq. 59) is required to fulfill the prescribed stoichiometry of the SOM pools $\left(\chi_{S O M}\right)$. These are assumed constant with the exception of the fast SOM C:N ratio, which varies with available $\mathrm{NH}_{4}$ following CENTURY (Parton et al., 1993):

$\chi_{S O M_{f a s t}^{C: N}}^{C: N}=\operatorname{MAX}\left(\chi_{S O M_{f a s t, \text { max }}^{C: N}}^{C: N}-f_{\chi} \times N H_{4}, \chi_{S O M_{f a s t, m i n}^{C: N}}^{C: N}\right)$

$$
\text { where } \chi_{S O M_{\text {fast } \text { min }}^{C: N}}, \chi_{S O M_{\text {fast }, \text { max }}^{C: N}} \text { and } f_{\chi} \text { are parameters. }
$$

The difference in stoichiometry of the matter entering the pool and the required stoichiometry of the pool leads to the estimate of the potential immobilisation flux:

$$
\Phi_{l \rightarrow \text { fast }, N H_{4}}^{*}=\frac{\eta_{C, \text { litter } \rightarrow \text { fast }}}{\chi_{S O M_{\text {fast }}^{C: N}}}\left(\frac{C_{m e t}}{\tau_{\text {met }}^{*}}+\frac{C_{\text {str }}}{\tau_{\text {str }}^{*}}\right)-\eta_{N}\left(\frac{N_{\text {met }}}{\tau_{\text {met }}^{*}}+\frac{N_{\text {str }}}{\tau_{\text {str }}^{*}}\right)
$$

where $\tau_{i}^{*}$ are the temperature and moisture constrained turnover times (Eq. 65).

The actual immobilisation rate $\left(\Phi_{l \rightarrow f a s t, N H_{4}}\right)$ is limited to the amount of ammonium $\left(\mathrm{NH}_{4}\right.$ available, subject to co-occurring potential $\mathrm{N}$ uptake from plants $\left(U_{N H_{4}, p l a n t}^{*}\right.$, Eq. 73), and nitrifiers $\left(U_{n i t}^{*}\right.$; Eq. 76). Note that, similar as for the plant uptake, 
the uptake of ammonium is limited with by Michaelis-Menten kinetics to account for reduced accessibility of $\mathrm{N}$ at very low values.

$\Phi_{l \rightarrow f a s t, N H_{4}}=\frac{N H_{4}}{\max \left(N_{4}, U_{N H_{4}, p l a n t}^{*}+U_{n i t}^{*}+\Phi_{l \rightarrow f a s t, N H_{4}}^{*}\right)} \times \Phi_{l \rightarrow f a s t, N H_{4}}^{*}$

In the case that $\Phi_{l \rightarrow f a s t, N H_{4}}$ is insufficient to ensure that the newly formed fast SOM has a C:N ratio of $\chi_{S O M_{f a s t}^{C: N}}$, the 5 turnover times of the metabolic and structural litter pool is increased to match the $\mathrm{N}$ available for immobilisation (Parton et al. (1993)):

$\tau_{m e t \mid s t r}=\tau_{m e t \mid s t r}^{*} \frac{\frac{\eta_{l \rightarrow f a s t, C}}{\chi_{S O M_{\text {fast }}^{C}: N}}\left(\frac{C_{m e t}}{\tau_{\text {met }}^{*}}+\frac{C_{s t r}}{\tau_{s t r}^{*}}\right)-\eta_{N}\left(\frac{N_{\text {met }}}{\tau_{\text {met }}^{*}}+\frac{N_{s t r}}{\tau_{s t r}^{*}}\right)}{\Phi_{l \rightarrow f a s t, N H_{4}}}$

Should the available $\mathrm{NH}_{4}$ be insufficient to maintain the uptake rates of plants (Eq. 73) and nitrifiers (Eq. 76), these fluxes are downregulated in proportion.

The potential immobilisation flux of phosphorus $\left(\Phi_{P, l \rightarrow f a s t}^{*}\right)$ is defined in a similar manner as potential $\mathrm{NH}_{4}$ immobilisation, but now considering the actual turnover time of the litter pools:

$$
\begin{aligned}
& \Phi_{P, l \rightarrow \text { fast }}^{*}=\frac{\eta_{C, l i t t e r \rightarrow \text { fast }}}{\chi_{S O M_{\text {fast }}^{\text {CaN }}} \chi_{S O M_{\text {fast }}^{N: P}}}\left(\frac{C_{m e t}}{\tau_{m e t}}+\frac{C_{\text {str }}}{\tau_{\text {str }}}\right)-\eta_{P}\left(\frac{P_{\text {met }}}{\tau_{\text {met }}}+\frac{P_{\text {str }}}{\tau_{\text {str }}}\right) \\
& \Phi_{P, l \rightarrow \text { fast }}=\frac{P_{4}}{\max \left(P_{4}, U_{P O_{4}, p l a n t}^{*}+\Phi_{P, l \rightarrow \text { fast }}^{*}\right)} \times \Phi_{P, l \rightarrow \text { fast }}^{*}
\end{aligned}
$$

Because the $\mathrm{C}: \mathrm{N}: \mathrm{P}$ stoichiometry and uptake use-efficiencies are organised such that decomposition of these pools is always

15 leading to net mineralisation of nutrients, the $\Phi_{\text {slow } \rightarrow \text { fast }}$ values are negative and do not require special treatment to affect the carbon-use efficiency or turnover rates (i.e. $\tau_{\text {fast }}=\tau_{\text {fast }}^{*}$, and $\tau_{\text {slow }}=\tau_{\text {slow }}^{*}$ ). The processing of fast and slow SOM is assumed to also include higher-order trophic levels of heterotrophic respiration Parton et al. (1993), therefore only a fraction of the respired material $\left(\eta_{C, \text { fast } \rightarrow \text { slow }}\right.$ and $\left.\eta_{C, \text { slow } \rightarrow \text { fast }}\right)$ is assumed to enter the subsequent pool:

$$
\begin{aligned}
& \Phi_{\text {fast } \rightarrow \text { slow }, N H_{4}}=\frac{\frac{\eta_{C, \text { fast } \rightarrow \text { slow }}}{\chi_{S O M_{\text {siow }}^{C: N}}} C_{\text {fast }}-N_{\text {fast }}}{\tau_{\text {fast }}} \\
& \Phi_{\text {slow } \rightarrow \text { fast }, \mathrm{NH}_{4}}=\frac{\frac{\eta_{C, \text { slow } \rightarrow \text { fast }}}{\chi_{S O M_{\text {fast }}^{\text {fas }}}} C_{\text {slow }}-N_{\text {slow }}}{\tau_{\text {slow }}}
\end{aligned}
$$

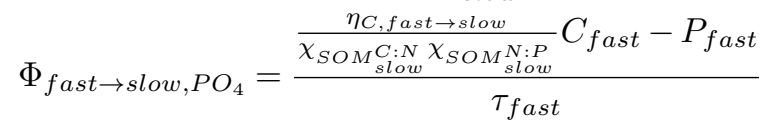

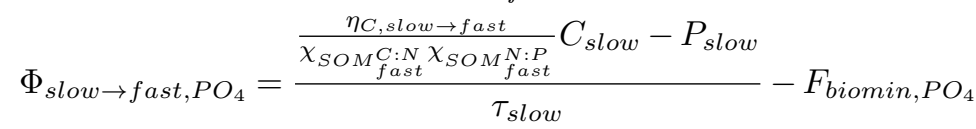




\subsection{Bioturbation}

Bioturbation is treated as simple diffusive flux with a rate constant $D_{b}$, as in Ahrens et al. (2015), but declining with soil depth in proportion to the fraction of roots in the layer to account for reduced biological activity with increasing soil depth:

$$
D_{b}=\frac{\text { root }_{\text {frac }}}{d z} \times \frac{k_{\text {org }}^{\text {diff }}}{\rho_{\text {soil }}^{\text {cor }}}, \text { and }
$$

5

$\rho_{\text {soil }}^{\text {cor }}=M A X\left(\rho_{\text {org }}^{\text {bulk }}, \rho_{O M}+\rho_{\text {soil }}-\rho_{O M} \frac{\rho_{\text {soil }}}{\rho_{\text {org }}^{\text {bulk }}}\right)$

where root $_{f r a c}$ and $d z$ are the root fraction and depth of the soil layer, $\rho_{\text {soil }}^{c o r}$ is the soil bulk density corrected with soil organic matter, $\rho_{\text {org }}^{\text {bulk }}$ is the bulk density of organic material, $\rho_{O M}$ is the organic matter density of the soil layer which depends on the organic matter content in the soil layer, $\rho_{\text {soil }}$ is the bulk density of fine mineral soil, and $k_{\text {org }}^{\text {diff }}$ is the diffusion coefficient for organic material due to bioturbation.

\subsection{Plant uptake rates}

The potential uptake rates of plants for $\mathrm{X}=\mathrm{NH}_{4}, \mathrm{NO}_{3}$, and $\mathrm{PO}_{4}$ follow an extended Michaelis-Menten kinetics:

$$
\begin{aligned}
& U_{X}^{*}=v_{\text {max }, X}\left(T_{\text {soil }}, \Psi\right) \times X \times\left(K_{m 1, X}\left(T_{\text {soil }}, \Theta\right)+\frac{1}{K_{m 2, X}\left(T_{\text {soil }}, \Theta\right)+X}\right) \times f_{\text {demand }}^{X} \times C_{\text {fine_root }}, \text { where } \\
& v_{\text {max }, X}\left(T_{\text {soil }}, \Psi\right)=v_{\text {max }, X} \frac{E_{d, \text { uptake }} \times e^{E_{a, \text { uptake }} \times T}}{E_{\text {d,uptake }}-E_{\text {a,uptake }} \times\left(1-e^{E_{d, \text { uptake }} \times T}\right)} \times \frac{\Psi_{\text {fine_root }}}{\Psi_{\text {leaf }, \text { min }}}, \text { with } \\
& T=\frac{T_{\text {soil }}-T_{\text {opt }, \text { uptake }}}{T_{\text {soil }} \times T_{\text {opt }, \text { uptake }} \times R} \text {, and } \\
& K_{m 1, X}\left(T_{\text {soil }}, \Theta\right)=K_{m 1, X} /\left(e^{-\frac{E a, h s c}{R} \times\left(\frac{1}{T_{s o i l}}-\frac{1}{T_{r e f}}\right)} \times\left(\frac{\Theta}{\Theta_{f c}}\right)^{k_{h s c}}\right), \text { and } \\
& K_{m 2, X}\left(T_{\text {soil }}, \Theta\right)=K_{m 2, X} \times e^{-\frac{E a, h s c}{R} \times\left(\frac{1}{T_{\text {soil }}}-\frac{1}{T_{\text {ref }}^{r}}\right)} \times\left(\frac{\Theta}{\Theta_{f c}}\right)^{k_{h s c}} \text {, and } \\
& f_{\text {demand }}^{X}=1-e^{-\left(\frac{\chi_{\max }^{X: Y}-\chi_{\text {labile }}^{X: Y}}{\left.\chi_{\max }^{X: Y \times\left(1-K_{\text {demand }}^{\text {half }}\right)}\right)^{k} \text { demand }}\right.}
\end{aligned}
$$$$
15
$$

where $v_{\max , X}$ is the PFT-specific temperature-sensitive maximum uptake rate per unit biomass, adjusted by the current root zone moisture potential ( $\Psi_{\text {fine_root }}$ ) to account for limited transport of nutrients towards the roots in dry soils, $C_{\text {fine_root }}$ is the biomass density of fine roots ( $\mathrm{mol} \mathrm{C} \mathrm{m}{ }^{-3}$, see Eq. 3 ), $T_{\text {soil }}$ is the soil temperature and the $K_{m}$ parameters are nutrient sensitivities of the low and high affinity transporters. These affinities are assumed to be temperature sensitive and are adjusted to soil moisture to account for the difference between mass-based and soil solution concentrations (Ahrens et al., 2015). The potential uptake of nutrients can be down-regulated by plants given their internal demand $f_{\text {demand }}^{X}$, where $X$ refers to either $\mathrm{N}$ or $\mathrm{P}$ and $X: Y$ refers to either $\mathrm{N}: \mathrm{C}$ or $\mathrm{P}: \mathrm{N}$ ratios. $\chi_{\max }^{X: Y}$ corresponds to the $\mathrm{X}: \mathrm{Y}$ ratio of growing a unit of leaves and fine roots at the current leaf-to-root ratio (see $3.4, K_{\text {demand }}^{\text {half, } X}$ is a parameter denoting the fraction of $\chi_{\max }^{X: Y}$ at which uptake is reduced to $50 \%$ and $k_{\text {demand }}$ is shape parameter. 


\subsection{Asymbiotic biological nitrogen fixation}

The asymbiotic biological nitrogen fixation (BNF) is represented as:

$F_{B N F}^{N H_{4}}=v_{\max , B N F} \times f\left(T_{\text {soil }}\right)$

where $v_{\max , B N F}$ is a parameter representing the base rate of fixation and the temperature response is calculated as above

5 (Eq. 65). $B N F$ is suppressed if the sum of $\mathrm{NH}_{4}$ and $\mathrm{NO}_{3}$ in any soil layer exceeds a critical threshold $N_{\text {limit }}^{B N F}$ (Zaehle et al., 2010). The distribution of $F_{B N F}^{N H_{4}}$ across soil layers follows the distribution of fine roots, as indicator for $\mathrm{C}$ inputs into the soil. All $\mathrm{N}$ fixed through this mechanism is added to the mineral $\mathrm{NH}_{4}$ soil pool.

\subsection{Nitrification and denitrification}

Calculation of nitrification and denitrification follows Xu-Ri and Prentice (2008); Zaehle et al. (2011), which relies on the separation of the soil into aerobic and anaerobic volume fractions $(a n v f)$ :

$$
\begin{gathered}
\text { anvf }=e^{-\left(\lambda_{a n v f} \times(1-a f p s)\right)^{k} \text { anvf }}, \text { where } \\
\text { afps }=\frac{W_{f c}-W_{\text {soil }}}{W_{f c}}
\end{gathered}
$$

where $\lambda_{a n v f}$ and $k_{a n v f}$ are parameters, afps is the air filled pore space, and the $W_{x}$ are the soil moisture contents as defined in Sect. 6.3.

The potential rate of nitrification $\left(U_{n i t}^{*}\right)$ in the aerobic fraction of the soil is modified by temperature and soil moisture according to:

$$
\begin{gathered}
U_{n i t}^{*}=v_{\text {max }, n i t} \times f\left(T_{\text {soil }}\right) \times g(\Theta) \times N H_{4}, \text { where } \\
f\left(T_{\text {soil }}\right)=E_{d, n i t} \frac{e^{\frac{E_{a, n i t} \times k t}{R_{g a s}}}}{E_{d, n i t}-E_{a, n i t} \times\left(1-e^{\frac{E_{d, n i t} \times k t}{R_{g a s}}}\right)} \\
k t=\frac{T_{\text {soil }}-T_{\text {opt }, \text { nit }}}{T_{\text {soil }} \times T_{\text {opt }, \text { nit }}}
\end{gathered}
$$

The actual rate of nitrification $\left(U_{\text {nit }}\right)$, given the potential rate and competing demands from plant and microbial uptake (Sect. 4.3, is partitioned into its products $\left(\mathrm{NO}_{3}, \mathrm{NO}_{\mathrm{y}}\right.$, and $\mathrm{N}_{2} \mathrm{O}$ ) according to

$$
\begin{aligned}
F_{n i t, N O_{3}} & =\left(1-f_{n i t} \mathrm{NO}_{y}-f_{n i t}^{\mathrm{N}_{2} \mathrm{O}}\right) \times U_{n i t} \\
F_{n i t, N O_{y}} & =f_{n i t}^{N O_{y}} \times U_{n i t} \\
25 \quad F_{n i t, N_{2} \mathrm{O}} & =f_{n i t}^{\mathrm{N}_{2} \mathrm{O}} \times U_{n i t}
\end{aligned}
$$


where the $F_{n i t, X}$ are the nitrification fluxes for $\mathrm{NO}_{3}, \mathrm{NO}_{y}$, and $\mathrm{N}_{2} \mathrm{O}$, respectively (Eq. 60).

The potential rate of denitrification $\left(U_{d e n i t}^{*}\right)$ in the anaerobic fraction of the soil is modified by temperature:

$$
\begin{gathered}
U_{\text {denit }}^{*}=\operatorname{anvf} \times v_{\text {max }, \text { denit }}\left(T_{\text {soil }}\right) \times \frac{C_{\text {fast }}}{K_{m, \text { denit }}^{\text {fast }}+C_{\text {fast }}} \frac{\mathrm{NO}_{3}}{K_{m, \text { denit }}^{N O_{3}}+N_{3}}, \text { where } \\
v_{\text {max }, \text { denit }}\left(T_{\text {soil }}\right)=v_{\text {max }, \text { denit }} \times e^{-\frac{E_{a, \text { denit }}}{R} \times\left(\frac{1}{T_{\text {soil }}}-\frac{1}{T_{\text {ref }}^{\tau}}\right)}
\end{gathered}
$$

5 The actual rate of denitrification $\left(U_{\text {denit }}\right)$, given the potential rate and competing demands from plant uptake (Sect. 4.3), is partitioned into its products $\left(\mathrm{NO}_{\mathrm{y}}, \mathrm{N}_{2} \mathrm{O}\right.$, and $\mathrm{N}_{2}$ ) according to

$$
\begin{aligned}
F_{\text {denit }, N O_{y}} & =f_{\text {denit }}^{\mathrm{NO}_{y}} \times U_{\text {denit }} \\
F_{\text {denit }, N_{2} O} O & =f_{\text {denit }}^{\mathrm{N}_{2} \mathrm{O}} \times U_{\text {denit }} \\
F_{\text {denit }, N_{2}} & =\left(1-f_{\text {denit }}^{\mathrm{NO}_{y}}-f_{\text {denit }}^{N O_{y}}\right) \times U_{\text {denit }}
\end{aligned}
$$

where the $F_{\text {denit,X }}$ are the denitrification fluxes for $\mathrm{NO}_{\mathrm{y}}, \mathrm{N}_{2} \mathrm{O}$, and $\mathrm{N}_{2}$, respectively (Eq. 60). The model currently ignores the effect of ammonia volatilisation, which is of low relevance for natural, unfertilised ecosystems.

\subsection{Phosphorus weathering and biomineralisation}

Weathering is modelled following Wang et al. (2010) as:

15

$$
\begin{gathered}
F_{\text {weath }, P O_{4}}=f\left(T_{\text {soil }}\right) \times g(\Theta) \times f\left(C_{\text {fine_root }}\right) \times k_{\text {weath }} \times \rho_{\text {soil }}^{\text {cor }}, \text { where } \\
f\left(T_{\text {soil }}\right)=e^{-\frac{E a, h s c}{R} \times\left(\frac{1}{T_{\text {soil }}}-\frac{1}{T_{\text {ref }}^{\tau}}\right)} \\
g(\Theta)=\left(\frac{\Theta}{\Theta_{f c}}\right)^{3}, \text { and } \\
f\left(C_{\text {fine_root }}\right)=\frac{C_{\text {fine_root }}}{K_{m, \text { weath }}^{\text {root }}+C_{\text {fine_root }}}
\end{gathered}
$$

where $k_{\text {weath }}$ is the rate constant for weathering, and $\rho_{\text {soil }}^{\text {cor }}$ is the soil bulk density corrected by SOM content. The weathering rate decreases with soil depth as the fine root $\mathrm{C}$ decreases, given the half-saturation root density $K_{m, \text { weath }}^{\text {root }}$, and is modified by soil temperature and moisture.

The potential biomineralisation rate of $\mathrm{PO}_{4}$ (McGill and Cole, 1981) is determined as an additional turnover of the $\mathrm{P}$ contained in the slow SOM pool, modified by temperature and moisture modifiers, and affected by the concentration of $\mathrm{PO}_{4}$ and the root biomass: 


$$
\begin{gathered}
F_{\text {biomin }, P O_{4}}^{*}=\frac{C_{\text {slow }}}{\chi_{S O M_{\text {slow }}^{C I N}} \times \chi_{S O M_{\text {slow }}^{N: P}} \times \tau_{\text {biomin }}} \times f\left(C_{\text {fine_root }}\right) \times f\left(P O_{4}\right) \times f\left(T_{\text {soil }}\right) \times g(\Theta), \text { where } \\
f\left(C_{\text {fine_root }}\right)=\frac{C_{\text {fine_root }}}{K_{m, \text { biomin }}^{\text {root }}+C_{\text {fine_root }}}, \text { and } \\
f\left(P O_{4}\right)=\frac{K_{m, \text { biomin }}^{P O_{4}}}{K_{m, \text { biomin }}^{P O_{4}}+P O_{4}}
\end{gathered}
$$

where $K_{m, \text { biomin }}^{\text {root }}$ and $K_{m, \text { biomin }}^{\mathrm{PO}_{4}}$ are constants constraining the biomineralisation rate under low root biomass and high $\mathrm{PO}_{4}$ 5 concentration, respectively; the temperature and moisture responses are calculated as those in Eq. 65 . The biomineralisation rate is further constrained so that it does not alter the stoichiometry of the fast pool.

$$
F_{\text {biomin }, P O_{4}}=\operatorname{MIN}\left(F_{\text {biomin }, P_{4}}^{*}, \frac{\frac{\eta_{C, s l o w \rightarrow \text { fast }}}{\chi_{S O M_{\text {slow }}^{C: N} \chi_{S O M}^{N: P}} M_{\text {slow }}} C_{\text {slow }}-P_{\text {slow }}}{\tau_{\text {slow }}}\right)
$$

\subsection{Phosphorus adsorption and (ab)sorption}

$\mathrm{PO}_{4}$ desorption follows Yang et al. (2014):

$10 F_{\text {desorp }, P O_{4}}=f\left(T_{\text {soil }}, E_{a, a b s}\right) \times k_{\text {abs }} \times P_{\text {lab }}-f\left(T_{\text {soil }}, E_{a, \text { des }}\right) \times k_{\text {des }} \times P_{\text {sorb }}$, where

$$
f\left(T_{\text {soil }, E_{a}}\right)=e^{-\frac{E_{a}}{R} \times\left(\frac{1}{T_{\text {soil }}}-\frac{1}{T_{\text {ref }}^{\tau}}\right)}
$$

where $k_{a b s}$ and $k_{d e s}$ are the rate constants of (ab)sorption and desorption, and $E_{a, a b s}$ and $E_{a, d e s}$ the respective activation energies.

The adsorption $\left(\mathrm{F}_{\text {adsorp }, \mathrm{PO}_{4}}\right)$ flux from soil solution to the soil adsorption sites is calculated assuming constant Langmuir 15 equilibrium (Barrow, 1978) between soluble and adsorbed P:

$$
\begin{aligned}
& P O_{4}=\frac{S_{\max } \times P O_{4}}{K_{S}+P_{4}}, \text { thus } \\
& \frac{\partial P_{l a b}}{\partial t}=\frac{S_{\max } \times P O_{4}}{\left(K_{S}+P O_{4}\right)^{2}} \frac{\partial O_{4}}{\partial t},
\end{aligned}
$$

by rearranging Eq. $84 \mathrm{~b}$

$$
\begin{aligned}
\frac{\partial P_{l a b}}{\partial t} & =k_{p} \frac{\partial\left(P_{l a b}+P O_{4}\right)}{\partial t} \\
20 \frac{\partial P O_{4}}{\partial t} & =\left(1-k_{p}\right) \frac{\partial\left(P_{l a b}+P O_{4}\right)}{\partial t}, \text { where }
\end{aligned}
$$

$k_{p}=\frac{S_{\max } \times P_{4}}{\left(K_{S}+P O_{4}\right)^{2}+S_{\max } P O_{4}}$,

where $S_{\max }$ and $K_{S}$ are the maximum sorption capacity, and the half-saturation concentration coefficient of the soil, and are modified by soil moisture and SOM content as follows: 


$$
\begin{aligned}
S_{\text {max }} & =\Theta_{\text {soil }} \times\left(S_{\text {om }}^{\text {max }} V_{\text {om }}^{\text {frac }} \rho_{\text {org }}^{\text {bulk }}+S_{\text {mineral }}^{\text {max }} V_{\text {mineral }}^{\text {frac }} \rho_{\text {soil }}\right), \text { and } \\
K_{S} & =K_{m, \text { om }}^{\text {sorb }} V_{\text {om }}^{\text {frac }} \rho_{\text {org }}^{\text {bulk }}+K_{m, \text { mineral }}^{\text {sorb }} V_{\text {mineral }}^{\text {frac }} \rho_{\text {soil }}
\end{aligned}
$$

where $V_{o m}^{\text {frac }}$ and $V_{\text {mineral }}^{\text {frac }}$ are volumetric fractions of organic matter and fine soil minerals, respectively. $S_{o m}^{m a x}$ and $S_{\text {mineral }}^{\text {max }}$ are the maximum $\mathrm{PO}_{4}$ sorption capacity of pure organic matter and pure fine soil, respectively. $K_{m, o m}^{\text {sorb }}$ and $K_{m, m i n e r a l}^{\text {sorb }}$ are

5 the half-saturation concentration coefficient of pure organic matter and pure fine soil, respectively.

Based on Eq.60f and Eq.61a, the equilibrium in Eq.84 could be solved .

$$
\begin{aligned}
\frac{\partial\left(P_{l a b}+P O_{4}\right)}{\partial t} & =F_{d e p, P O_{4}}+F_{\text {weath }, P O_{4}}+F_{\text {biomin }, P O_{4}}-U_{\text {plant }, P O_{4}}-F_{\text {desorp }, P O_{4}} \\
& -\sum\left(\Phi_{i, P O_{4}}\right)-\frac{\partial v_{P O_{4}} P O_{4}}{\partial z}+\frac{\partial}{\partial z}\left(D_{b} \frac{\partial P_{l a b}}{\partial z}\right)
\end{aligned}
$$

\subsection{Soil in- and outfluxes}

Currently, gas diffusion is not modelled explicitly. Instead, $\mathrm{CO}_{2}$ is assumed to be directly released to the atmosphere. The

$$
F_{C O_{2}}^{\uparrow}=\left(\left(1-\eta_{C, \text { litter } \rightarrow \text { fast }}\right)\left(\frac{C_{\text {met }}}{\tau_{\text {met }}}+\frac{C_{\text {str }}}{\tau_{\text {str }}}\right)+\left(1-\eta_{C, w l \rightarrow \text { met } \mid \text { str }}\right) \frac{C_{w l}}{\tau_{w l}}+\left(1-\eta_{C, \text { fast } \rightarrow \text { slow }}\right) \frac{C_{\text {fast }}}{\tau_{\text {fast }}}+\left(1-\eta_{C, \text { slow } \rightarrow \text { fast }}\right) \frac{C_{\text {slow }}}{\tau_{\text {slow }}}\right) \Delta t
$$

and similar for ${ }^{13} \mathrm{C}$ and ${ }^{14} \mathrm{C}$ fluxes. Slightly differently from that, the emission of gaseous $\mathrm{N}$ species is assumed to follow Xu-Ri and Prentice (2008), which considers the effect of temperature and moisture on gas loss. However, transfer between soil layers is equally not treated explicitly.

$$
\begin{aligned}
F_{X}^{\uparrow} & =f\left(T_{\text {soil }}\right) \times \text { afps } \times X, \text { where } \\
f\left(T_{\text {soil }}\right) & =e^{-\frac{E_{a, d i f f}}{R} \times\left(\frac{1}{T_{\text {soil }}}-\frac{1}{T_{\text {ref }}^{\tau}}\right)}
\end{aligned}
$$

and afps is the air-filled pore fraction of the soil (see Eq. 75.)

\section{Isotopic composition and fractionation}

The carbon $(\mathrm{C})$ and nitrogen $(\mathrm{N})$ flows and pool tracked in the model are comprising all major isotopes $\left(\mathrm{i} . \mathrm{e} . \mathrm{C}={ }^{12} \mathrm{C}+{ }^{13} \mathrm{C}\right.$ $20+{ }^{14} \mathrm{C}$, and $\mathrm{N}={ }^{14} \mathrm{~N}+{ }^{15} \mathrm{~N}$ ). The model explicitly tracks the mass flow of ${ }^{13} \mathrm{C},{ }^{14} \mathrm{C}$ and ${ }^{15} \mathrm{~N}$ as separate entities for all 
biogeochemical pools and fluxes. The molar mixing ratio $\left(R_{X}\right)$ of the isotope (e.g. $\left.{ }^{13} \mathrm{C}\right)$ to the main element (e.g. $\left.{ }^{12} \mathrm{C}\right)$ of each biogeochemical pool can be calculated as

$R_{13 C}=\frac{{ }^{13} C}{{ }^{12} C}=\frac{{ }^{13} C}{C-{ }^{13} C}$

and by convention

$5 \quad \delta_{13 C}=\left(\frac{R_{13 C}}{R_{r e f, 13 C}}-1\right) \times 1000$

where $R_{r e f, 13 C}$ is the reference isotopic molar mixing ratio and $\delta_{13 C}$ is in \%o. Similar calculations are done for the ratio of ${ }^{15} \mathrm{~N}$ to ${ }^{14} \mathrm{~N}$ and the reference value $R_{r e f, 15 N}$. By convention, the delta notation of ${ }^{14} \mathrm{C}$ is dependent on the ${ }^{13} \mathrm{C}$ content, see (Levin et al., 2010), and the molar mass of ${ }^{14} \mathrm{C}$ is ignored in the calculations of ${ }^{13} \mathrm{C}$ because of the extremely low concentrations.

Biogeochemical processes discriminate against the heavier isotope, and this fractionation process is treated by calculating the mixing ratio of the isotope of the resulting flux as

$$
R_{\text {sink }}=\frac{R_{\text {source }}}{\frac{\epsilon_{\text {process }}+1}{1000}+1}
$$

where $R_{\text {source }}$ is the molar mixing ratio of the source pool of the reaction, $R_{\text {sink }}$ is the molar mixing ratio of the resulting matter flux, and $\epsilon_{\text {process }}$ is a process and isotope specific discrimination rate.

Isotopic discrimination of ${ }^{13} \mathrm{C}$ and ${ }^{14} \mathrm{C}$ by photosynthesis is modelled according to the general equation derived by Farquhar et al. (1982); Drake (2014), so that

$D_{x}=a_{x}+\left(c_{x}+\phi_{C 4} \times b_{x}-a_{x}\right) \frac{c_{i}}{c_{a}}$

where $a_{x}$, and $b_{x}$ are isotope-specific constants $\left({ }^{13} \mathrm{C}\right.$ and ${ }^{14} \mathrm{C}$, respectively, see Table 5). $c_{x}$ and $\phi_{C 4}$ account for the additional bundle-sheath processes in $\mathrm{C} 4$ plants. For $\mathrm{C} 3$ plants, these processes do not play a role and these parameters are 0 and 1 , respectively. In the model, currently only photosynthesis is assumed to result in C-isotope discrimination, ignoring the effect of the smaller and uncertain discrimination by tissue construction, storage formation and respiration (Brüggemann et al., 2011).

Isotopic discrimination for various nitrogen cycle processes (biological nitrogen fixation, ammonification, plant and microbial $\mathrm{N}$ uptake, and processes associated with nitrification and denitrification) are taken from (Robinson, 2001). According to (Robinson, 2001), in case of near-complete consumption of the source pool, the discrimination is reduced as

$25 \epsilon_{\text {process }}^{\text {corr }}=\epsilon_{\text {process }}\left(f_{\text {source }}-1\right) \log \left(\frac{1-f_{\text {source }}}{f_{\text {source }}}\right)$

where $f_{\text {source }}$ is the ratio of the source consumption to the source pool size. 


\section{Radiation, surface energy balance and soil hydrology}

\subsection{Net surface shortwave radiation budget}

Canopy radiation interception is calculated with a multi-layer scheme following Spitters (1986), with radiation levels calculated at the mid-point of each canopy layer. The scheme uses up to 20 (default 10) canopy layers, with exponentially increasing layer thickness as the canopy depth increases. The original scheme has been extended to diagnose canopy albedo, to account for

5 smooth transition of surface albedo from soil to vegetation values with increasing leaf coverage.

The scheme is applied separately to the visible (vis) and near-infrared (nir) radiation band, where the parameterisation of the visible radiation is based on the assumption that the radiation interception and reflection are similar to that of the photosynthetically active range (i.e. $400-700 \mathrm{~nm}$ ). In the following, the subscripts for visible and near-infrared are omitted for readability.

The reflection coefficient $\left(\rho_{\text {rad }}\right)$ of the green canopy is given by:

$\rho_{\text {rad }}=\frac{1-\sqrt{1-\sigma}}{1+\sqrt{1-\sigma}} \times \frac{2}{1+\rho^{s b e t a} \times \cos \left(\gamma^{*}\right)}$,

where the first term on the right hand side is the reflection of a horizontally oriented canopy, and the second term empirically adjusts the reflection to a spherical distribution. $\sigma$ is the PFT-specific single leaf scattering coefficient and $\rho^{\text {sbeta }}$ is a conversion constant. Because all equations for leaf reflection and absorption coefficients are only valid for high solar elevation, the true zenith angle $(\gamma)$ is constrained to values larger than $10^{\circ}\left(\gamma^{*}\right)$. Note that Spitters (1986) use the sine of the solar elevation angle.

For a spherical leaf angle distribution with leaves distributed randomly within the canopy volume, the extinction coefficients of the diffuse flux $\left(k_{d f}\right)$ and that of the direct component of the direct flux $\left(k_{b l}\right)$ are approximated, respectively, by:

$k_{d f}=k_{d f, 0} \sqrt{1-\sigma} \times \Omega$

$20 \quad k_{b l}=\frac{k_{b l, 0} \times \Omega}{\cos \left(\gamma^{*}\right)}$

where $\Omega$ is the clumping index according to Campbell and Norman (1998), which is calculated as:

$\Omega=\Omega_{0} /\left(\Omega_{0}+\left(1-\Omega_{0}\right) \times e^{-k_{c s f} \times a \cos \left(\gamma^{*}\right)^{\phi} \text { crown }}\right)$,

where $\Omega_{0}$ and $\phi_{\text {crown }}$ are the PFT-specific clumping factor at nadir and crown shape factor, respectively, and $k_{c s f}$ is a correction factor.

Light levels decrease exponentially in the canopy, such that the attenuation of direct $(d r)$ and diffuse $(d f)$ top-of-the-canopy irradiance ( $I_{d r \downarrow, 0}$ and $I_{d f \downarrow, 0}$, respectively) at any cumulative leaf area index ( $L A I_{c}$; from the top) is given by: 


$$
\begin{aligned}
& I_{d f \downarrow}=\left(1-\rho_{r a d}\right) \times I_{d f \downarrow, 0} \times e^{-k_{d f} \times L A I_{c}} \\
& I_{d r \downarrow}=\left(1-\rho_{r a d}\right) \times I_{d r \downarrow, 0} \times e^{-\sqrt{1-\sigma} \times k_{b l} \times L A I_{c}} \\
& I_{d r, d r \downarrow}=I_{d r \downarrow, 0} \times e^{-k_{b l} \times L A I_{c}} \\
& I_{d r, d f \downarrow}=I_{d r \downarrow}-I_{d r, d r \downarrow}
\end{aligned}
$$

where $I_{d r, d f \downarrow}$ is the diffuse part of the direct beam resulting from scattering of the direct beam and $I_{d r, d r \downarrow}$ is the direct beam remaining direct at the canopy depth $L A I_{c}$.

Below the canopy $(b c)$, i.e. at the soil surface, the downwelling energy flux $\left(I_{b c \downarrow}\right)$ is divided into a part that is absorbed by the soil $\left(I_{a, s o i l}\right)$ and a part that is backscattered as diffuse radiation $\left(I_{b c \uparrow}\right)$, depending on the soil's albedo $\left(a_{l} b_{\text {soil }}\right)$ :

$$
\begin{aligned}
I_{b c \downarrow} & =\left(1-\rho_{\text {rad }}\right) \times\left(I_{d f \downarrow, 0} \times e^{-k_{d f} \times L A I}+I_{d r \downarrow, 0} \times e^{-\sqrt{1-\sigma} \times k_{b l} \times L A I}\right) \\
10 \quad I_{a, \text { soil }} & =\left(1-a l b_{s o i l}\right) \times I_{b c \downarrow} \\
I_{b c \uparrow} & =a l b_{\text {soil }} \times I_{b c \downarrow}
\end{aligned}
$$

To first-order, the diffuse light profile of the canopy accounting for the backscatter of diffuse radiation from the soil can be approximated as

$$
I_{d f \downarrow \uparrow}=\left(1-\rho_{\text {rad }}\right) \times\left(I_{d f \downarrow, 0} \times e^{-k_{d f} \times L A I_{c}}+\times I_{b c \uparrow} \times e^{\left.-k_{d f} \times\left(L A I-L A I_{c}\right)\right)}\right.
$$

15 Absorption $\left(A^{r a d}\right)$ is taken to be complementary to transmission, therefore the absorbed diffuse and direct energy flux at a cumulative leaf area $L A I_{c}$ can be written as:

$$
\begin{aligned}
& A_{d f}^{r a d}=k_{d f} \times I_{d f \downarrow \uparrow} \\
& A_{d r}^{r a d}=(1-\sigma) \times k_{b l} \times I_{d r} \\
& A_{d r, d r}^{r a d}=(1-\sigma) \times k_{b l} \times I_{d r \downarrow, 0} \times e^{-k_{b l} \times L A I_{c}}
\end{aligned}
$$

$20 A_{d r, d f}^{r a d}=A_{d r}^{r a d}-A_{d r, d r}^{r a d}$

The canopy is then split into a sunlit and a shaded part, with the sunlit fraction defined as:

$$
f_{\text {sunlit }}=e^{-k_{b l} \times L A I_{c}}
$$

following eq. 97c. The sunlit part receives both diffuse and direct radiation, whereas the shaded part only received diffuse radiation. Thus,

$$
\begin{aligned}
& A_{\text {shaded }}^{\text {rad }}=A_{d f}^{r a d}+A_{d r, d f}^{r a d} \\
& A_{\text {sunlit }}^{r a d}=A_{\text {shaded }}^{r a d}+(1-\sigma) \times k_{b l} \times I_{d r \downarrow, 0}
\end{aligned}
$$


$a l b_{\text {can }}=1-\frac{I_{b c \downarrow}+\left(1-f_{\text {sunlit }}\right) \times A_{\text {shaded }}^{\text {rad }}+f_{\text {sunlit }} \times A_{\text {sunlit }}^{\text {rad }}}{I_{d f \downarrow, 0}+I_{d r \downarrow, 0}}$

The total shortwave upward flux is diffuse and calculated as the backscattered flux of the canopy plus the backscattered flux from the soil, which is transmitted diffusely through the canopy:

$I_{d f \uparrow}=a l b_{c a n} \times\left(I_{d f \downarrow, 0}+I_{d r \downarrow, 0}-I_{b c \downarrow}\right)+\left(1-\rho_{r a d}\right) \times I_{b c \uparrow} \times e^{-k_{d f} \times L A I}$

5 Based on this, the total surface albedo $a l b_{\text {surf }}$ (i.e. the albedo derived from vegetation and soil radiation transfer, absorption, and reflection) and net shortwave flux $I_{n e t}$ can be calculated as:

$$
\begin{aligned}
& a l b_{\text {surf }}=\frac{I_{d f \uparrow}}{I_{d f \downarrow, 0}+I_{d r \downarrow, 0}} \\
& I_{n e t}=\left(1-a l b_{\text {surf }}\right) \times\left(I_{d f \downarrow, 0}+I_{d r \downarrow, 0}\right)
\end{aligned}
$$

\subsection{Surface energy balance}

10 The representation of the surface energy balance including the turbulent momentum and heat exchanges, surface, and soil temperature calculations follows largely the scheme of JSBACH 3, as described by Roeckner et al. (2003). The net radiation $\left(R_{n e t}\right)$ at the surface consists of the following components:

$R_{n e t}=\left(1-\alpha_{s}\right) R_{s d}+R_{l d}-\epsilon \sigma_{S B} T_{s}^{4}$

where the term $\alpha_{s} \times R_{s d}$ is the net surface shortwave balance, denoted as $I_{n e t}$ in Eq. 105, $R_{l d}$ the downwelling longwave radiation, $\epsilon$ the surface emissivity, $\sigma_{S B}$ the Stefan-Boltzmann constant, and $T_{s}$ is the surface temperature.

The surface energy balance can then be written as

$C_{s, l} \frac{\partial T_{s}}{\partial t}=R_{n e t}+L E+H+G$

where $C_{s, l}$ is the heat capacity of the surface layer, $H$ is the sensible heat flux, $L E$ the latent heat flux, composed of interception loss $E_{i}$, soil evaporation $E_{s}$ and transpiration $E_{v}$, as described in Section 6.3. $G$ is the ground heat flux, which is obtained from the solution of the thermal diffusion equation, which is used to diagnose the temperature profile within the soil

$C_{s} \frac{\partial T}{\partial t}=-\frac{\partial G}{\partial z}=-\frac{\partial}{\partial z}\left(-\lambda_{s} \frac{\partial T}{\partial z}\right)$

where $C_{s}$ is the volumetric heat capacity of the soil, $G$ is the thermal heat flux (positive downward), $\lambda_{s}=C_{s} \kappa_{s}$ is the thermal conductivity, $\kappa_{s}$ the thermal diffusivity, both derived from soil texture, and $z$ the depth. This equation is solved down 
to a prescribed depth assuming zero flux conditions at the bottom and surface temperature $T_{s}$ at the top as obtained from Eq. 107.

The sensible heat flux $H$ is obtained from the temperature gradient according to

$H=\rho_{a i r} C_{p} \frac{T_{a i r}-T_{s}}{r_{a}}$

where $\rho_{a i r}$ and $C_{p}$ are density and heat capacity of the surface atmospheric layer, and $T_{a i r}$ and $T_{s}$ are air and surface

5 temperature. $r_{a}$ is the aerodynamic resistance:

$r_{a}=\left(C_{h}\left|v_{h}\right|\right)^{-1}$

and depends on the transfer coefficient for heat $C_{h}$ Roeckner et al. (2003). and the absolute value of horizontal wind velocity $v_{h}$.

\subsection{Surface and soil hydrology}

10 The soil model keeps track of water in terms of amount of water $\left(W_{\text {skin } \mid \text { soil }} ; \mathrm{m}\right)$, which in the soil can be converted to the layers fractional water content $(\Theta)$ as:

$\Theta_{\text {soil }, s l}=\frac{W_{\text {soil }, s l}}{d z_{s l}}$

with a soil water matrix potential ( $\Psi_{\text {soil }, s l}$ ) derived from a pedotransfer function Saxton and Rawls (2006) as follows:

$\Psi_{\text {soil }, s l}=k_{A}^{\Psi} \Theta_{\text {soil }, s l}^{k_{B}^{\Psi}}$

where $k_{A}^{\Psi}$, and $k_{B}^{\Psi}$ are soil texture dependent parameters Saxton and Rawls (2006).

Precipitation (Precip) becomes partially intercepted by the canopy before reaching the soil:

$F_{\text {inter }}=M I N\left(k_{\text {eff }, \text { inter }} \times\right.$ Precip,,$\left.\frac{w_{\text {skin }, \max } \times L A I-W_{\text {skin }}}{d t}\right)$

within the limit of the maximum size of this reservoir, where $w_{s k i n, \max }$ is a parameter. Different from Roeckner et al. (2003), the remaining throughfall is partitioned in the first soil layer into infiltration $\left(F_{i n f}\right)$, within the limits of its field capacity $\left(\Theta_{f c}\right)$, surface runoff $\left(F_{\text {runoff }}\right)$, and a fraction that is leaked to the next layer along preferential flow pathways $\left(F_{\text {pref }}\right)$ :

$$
\begin{aligned}
F_{\text {input }} & =\operatorname{MIN}\left(\text { Precip }-F_{\text {inter }}, \frac{W_{f c, s l=1}-W_{\text {act }, \text { sl }=1}}{d t}\right), \\
F_{\text {inf }} & =\left(1-\frac{k_{\text {pref }}}{d z_{\text {sl }}}\right) F_{\text {input }} \\
F_{\text {runoff }} & =\left(1-k_{\text {pref }, \text { runoff } f}\right)\left(F_{\text {through }}-F_{\text {input }}\right), \text { and } \\
F_{\text {pref }, \text { sl }=1} & =\frac{k_{\text {pref }}}{d z_{\text {sl }}} F_{\text {inf }}+k_{\text {pref }, \text { runoff }}\left(F_{\text {through }}-F_{\text {input }}\right)
\end{aligned}
$$


$\begin{aligned} F_{d i f f, s l-1 \rightarrow s l} & =\frac{\bar{K}_{d i f f, s l-1 \rightarrow s l}}{0.5 \times\left(d z_{s l-1}+d z_{s l}\right)}\left(\Psi_{\text {soil }, s l}-\Psi_{\text {soil }, s l-1}\right), \text { where } \\ \bar{K}_{d i f f, s l-1 \rightarrow s l}= & \frac{d z_{s l-1} K_{d i f f, s a t, s l-1}\left(\frac{\Theta_{a c t, s l-1}}{\Theta_{s a t, s l-1}}\right)^{k_{C, s l}^{d i f f}}+d z_{s l} K_{d i f f, s a t, s l}\left(\frac{\Theta_{a c t, s l}}{\Theta_{s a t, s l}}\right)^{k_{C, s l}^{d i f f}}}{d z_{s l-1}+d z_{s l}}\end{aligned}$

where $K_{d i f f, s a t, s l}$ and $k_{C, s l}^{\text {diff }}$ are derived from soil texture according to Saxton and Rawls (2006).

$E_{i}=\rho_{a i r} \frac{q_{a}-q_{s}\left(T_{s}, p_{s}\right)}{r_{a}} \frac{W_{\text {skin }}}{w_{\text {skin, } \max } \times L A I}$,

where $\rho_{\text {air }}$ is air density, $q_{a}$ specific humidity in lowest atmospheric level, $q_{s}$ saturation specific humidity at surface temperature $T_{s}$ and pressure $p_{s}$, and ratio of the size of the canopy water storage $\left(W_{s k i n}\right)$ and the maximum size of this reservoir, where $w_{\text {skin, } \max }$ is a parameter, and $L A I$ is the current leaf area index of the vegetation.

Evaporation from the soil surface is calculated as:

$E_{s}=\rho_{a i r} \frac{q_{a}-q_{s}\left(T_{s}, p_{s}\right)}{r_{a}^{*}} \Theta_{s o i l, 1}\left(1-\exp \left(k_{f p c} \times L A I\right)\right)$

where $\Theta_{\text {soil, } 1}$ the fractional soil water content of the first soil layer. The term $\left(1-\exp \left(k_{f p c} \times L A I\right)\right)$ has been added to the model of Roeckner et al. (2003) to account for the reduced energy available for evaporation underneath a closed canopy.

Transpiration from the dry vegetation surfaces is

$E_{v}=\rho_{a i r} \frac{q_{a}-q_{s}\left(T_{s}, p_{s}\right)}{r_{a}+r}$

where stomatal resistance $r$ of the canopy is the inverse of the stomatal conductance of the canopy (see Eq. 17).

The partitioning of the transpiration flux across soil layers $f_{\text {trans }, s l}$ is calculated based on the layered soil water potential $\left(\Psi_{\text {soil }, s l}\right)$, the fractional root distribution $\left(f_{\text {root }, s l}\right)$, as well as a PFT-specific minimum soil water potential,

$$
\begin{aligned}
f_{\text {trans }, s l} & =\frac{f_{\text {root }, \text { sl }} \times \beta_{g s, \text { soil }, \text { sl }}}{\sum_{i=1}^{n} f_{\text {root }, i} \times \beta_{g s, \text { soil }, i}}, \text { where } \\
\beta_{g s, \text { soil }, s l}= & \Psi_{\text {soil }, \text { sl }} / \Psi_{\text {soil }, \text { min }}
\end{aligned}
$$


Based on these fluxes, the water budget can be described as follows

$$
\begin{aligned}
\frac{W_{\text {skin }}}{d t} & =F_{\text {inter }}-E_{i} \\
\frac{W_{\text {soil }, s l=1}}{d t} & =F_{\text {inf }}-E_{a}-f_{\text {frans }, s l=1} E_{v}-F_{d i f f, s l=1 \rightarrow s l=2} \\
\frac{W_{\text {soil }, s l=2, n}}{d t} & =\left(1-\frac{k_{\text {pref }}}{d z_{s l}}\right) F_{\text {pref }, s l-1}-f_{\text {frans }, s l} F_{\text {trans }}+F_{\text {diff }, s l-1 \rightarrow s l}-F_{\text {diff }, s l \rightarrow s l+1}
\end{aligned}
$$

5 Saturation of a soil layer leads to increased percolation to the next lower layer. The lower boundary layer in the soil is modelled as a zero gradient boundary, i.e. only percolation flow leads to drainage from the soil column. The net water transport between layers is used as input to the vertical flow of soluable biogeochemical pools. 
Table 1. Memory time scale for processes

\begin{tabular}{|l|l|c|}
\hline Symbol & Description & Unit \\
\hline$\tau_{\text {mavg }}^{\text {soa }}$ & Frost response of photosynthesis (state-of-acclimation) & days \\
$\tau_{\text {mavg }}^{\text {uptake }}$ & Demand for nutrient uptake & days \\
$\tau_{\text {mavg }}^{\text {labile }}$ & Labile pool dynamics & days \\
$\tau_{\text {mavg }}^{\text {pheno }}$ & Phenological processes & days \\
$\tau_{\text {mavg }}^{\text {jmax }}$ & Acclimation of temperature optimum for photosynthesis & days \\
$\tau_{\text {mavg }}^{\chi}$ & Response of foliar stoichiometry & days \\
$\tau_{\text {mavg }}^{\text {resp }}$ & Acclimation of respiration & 7 \\
$\tau_{\text {mavg }}^{\text {dynamics }}$ & Vegetation dynamics processes & days \\
$\tau_{\text {mavg }}^{\text {alloc }}$ & Allometric responses & days \\
\hline
\end{tabular}

Table 2. Photosynthesis parameters

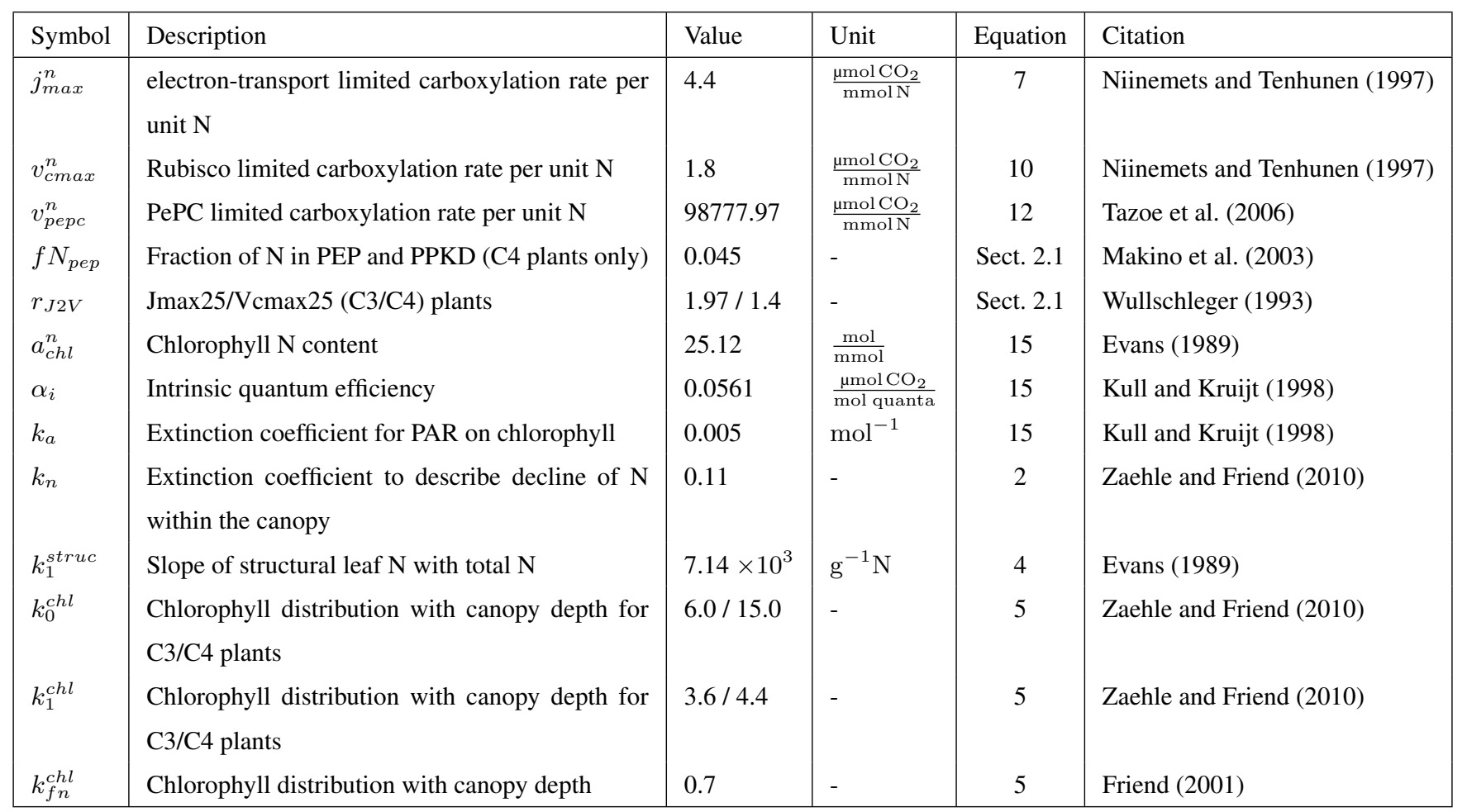


Table 2. Photosynthesis parameters (ctnd.)

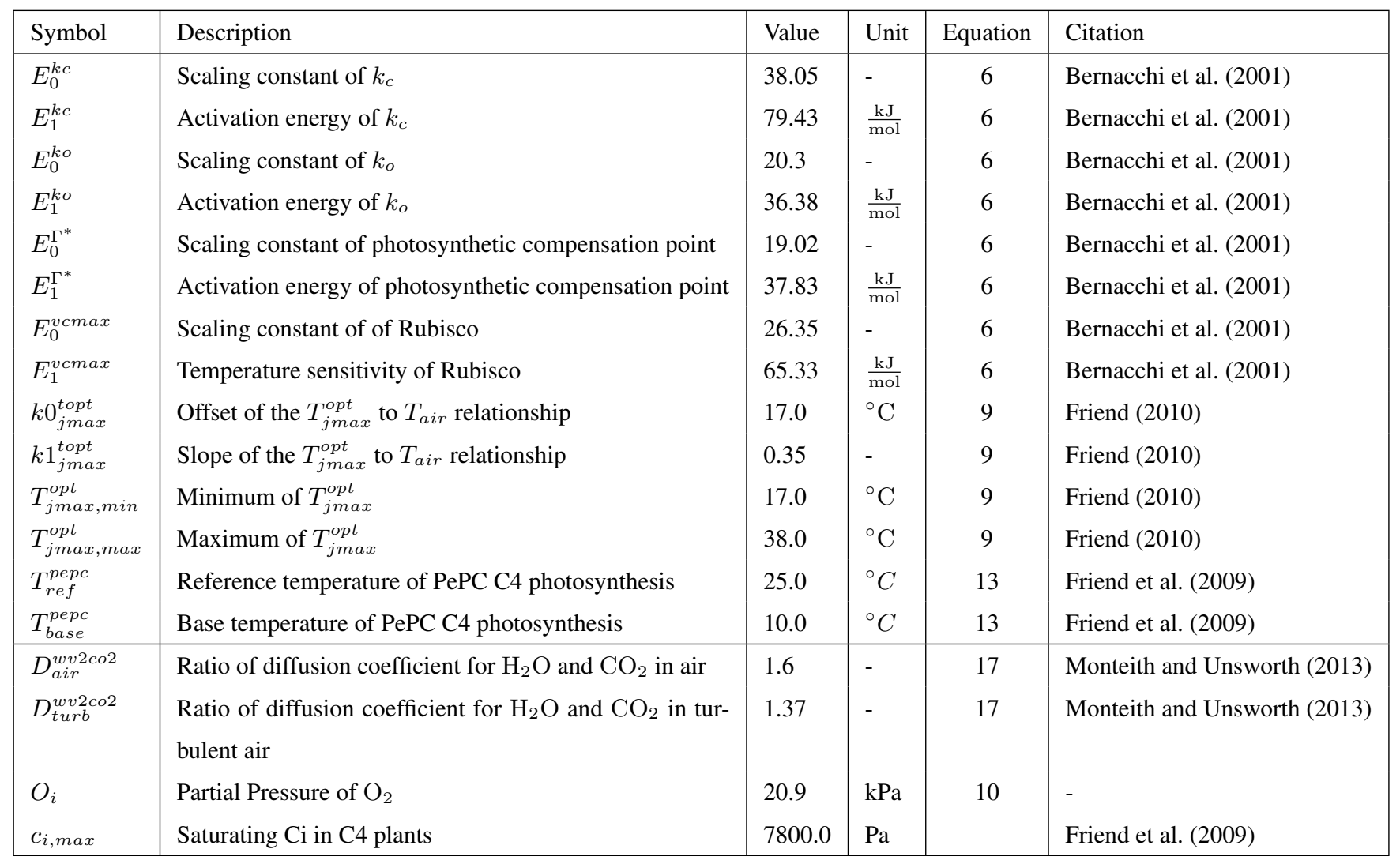


Table 3. Vegetation growth and dynamics parameters

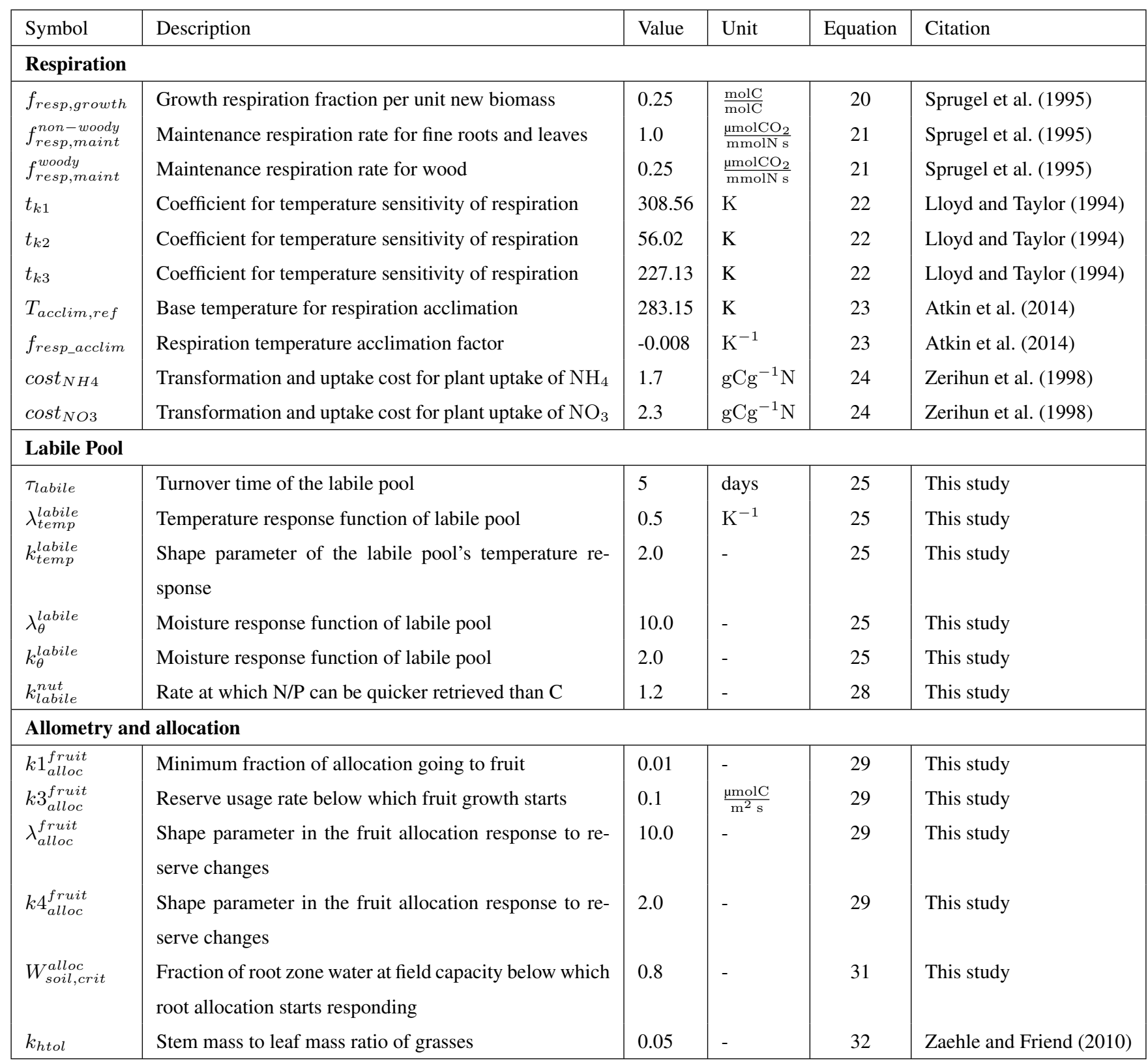


Table 3. Vegetation growth and dynamics parameters (ctnd.)

\begin{tabular}{|c|c|c|c|c|c|}
\hline Symbol & Description & Value & Unit & Equation & Citation \\
\hline$C_{m}$ & Carbon mass per unit dry weight of leaves & 0.48 & $\frac{\mathrm{gC}}{\mathrm{gDW}}$ & - & Kattge et al. (2011) \\
\hline$\chi_{\text {root }}^{C: N}$ & Relative $\mathrm{C}: \mathrm{N}$ of fine roots compared to leaves & 0.85 & - & Sect. 3.5 & Zaehle and Friend (2010) \\
\hline$\chi_{w o o d}^{C: N}$ & Relative C:N of woody biomass compared to leaves & 0.145 & - & Sect. 3.5 & Zaehle and Friend (2010) \\
\hline$\chi_{\text {root }}^{N: P}$ & Relative N:P of fine roots compared to leaves & 1.0 & - & Sect. 3.5 & This study \\
\hline$\delta_{\text {leaf }}^{\chi}$ & Maximum rate of foliar stoichiometry change & 0.0048 & day $^{-1}$ & 36 & (Zaehle and Friend, 2010) \\
\hline$\lambda_{\text {leaf }}^{\chi}$ & Shape parameter in leaf stoichiometry nutrient response & 2.0 & - & 37 & (Zaehle and Friend, 2010) \\
\hline$k_{\text {leaf }}^{\chi}$ & Shape parameter in leaf stoichiometry nutrient response & 8.0 & - & 37 & (Zaehle and Friend, 2010) \\
\hline \multicolumn{6}{|c|}{ Reserve dynamics } \\
\hline$k_{\text {maint }, C}^{\Phi}$ & Shape parameter for pull from reserve $\mathrm{C}$ to labile $\mathrm{C}$ pools & 1.2 & - & 40 & This study \\
\hline$k_{\text {maint }, N P}^{\Phi}$ & $\begin{array}{l}\text { Shape parameter for pull from reserve NIP to labile NIP } \\
\text { pools }\end{array}$ & 1.6 & - & 40 & This study \\
\hline$\lambda_{\text {maint }, N P}^{\Phi}$ & $\begin{array}{l}\text { Shape parameter for pull from reserve NIP to labile NIP } \\
\text { pools }\end{array}$ & 3.0 & - & 40 & This study \\
\hline$\lambda_{\text {store }}^{\Phi}$ & Shape parameter for pull from labile to reserve pool & 2.0 & - & 40 & This study \\
\hline$k_{\text {store }}^{\Phi}$ & Shape parameter for pull from labile to reserve pool & 3.0 & & 40 & This study \\
\hline$\lambda_{\text {phen }}^{\Phi}$ & $\begin{array}{l}\text { Shape parameter in storage response function to phenol- } \\
\text { ogy }\end{array}$ & 1.3 & - & 42 & This study \\
\hline$k_{\text {sinklim }}^{C N P}$ & Photosynthetic sink limitation with nutrient limitation & 4.0 & - & 44 & This study \\
\hline$\beta_{\text {sinklim,min }}^{\text {ps }}$ & Lower bound of photosynthetic sink limitation & 0.25 & - & 43 & This study \\
\hline$f_{\text {store }, \max }^{l e a f}$ & Maximum reserve storage in leaves relative to leaf mass & 0.02 & - & Sect. 3.6 & This study \\
\hline$f_{\text {store }, \max }^{\text {root }}$ & $\begin{array}{l}\text { Maximum reserve storage in fine roots relative to fine } \\
\text { root mass }\end{array}$ & 0.2 & - & Sect. 3.6 & This study \\
\hline$f_{\text {store }, \text { max }}^{\text {wood }}$ & $\begin{array}{l}\text { Maximum reserve storage in sap wood relative to sap } \\
\text { wood mass }\end{array}$ & 0.15 & - & Sect. 3.6 & This study \\
\hline$k_{\Phi}^{\text {inter }}$ & $\begin{array}{l}\text { Threshold value of } \Phi_{\text {maint }}^{X} \text { beyond which } \Phi_{\text {store }}^{X} \text { is re- } \\
\text { duced }\end{array}$ & 0.75 & - & 41 & This study \\
\hline
\end{tabular}


Table 3. Vegetation growth and dynamics parameters (ctnd.)

\begin{tabular}{|c|c|c|c|c|c|}
\hline Symbol & Description & Value & Unit & Equation & Citation \\
\hline$t_{\text {air }}^{G D D}$ & $\begin{array}{l}\text { Temperature threshold for the accumulation of growing } \\
\text { degree days }\end{array}$ & ${ }^{\circ} \mathrm{C}$ & 5 & - & by convention \\
\hline$\tau_{\text {soa }}$ & Time constant in calculation state of acclimation & 114 & hours & 46 & This study \\
\hline$T_{\text {min }}^{\text {soa }}$ & Min temp. in $\beta_{\text {soa }}$ calculation & -3 & ${ }^{\circ} \mathrm{C}$ & 47 & This study \\
\hline \multicolumn{6}{|l|}{ Turnover } \\
\hline$\tau_{n u t \_r e c y c l e}$ & Time scale of foliar and fine root nutrient turnover & 10.0 & days & 48 & Zaehle and Friend (2010) \\
\hline$f_{\text {shed, } \max }$ & Maximum rate of leaf shedding & 0.05 & days & 49 & This study \\
\hline$k_{\text {resorb }}^{\text {leaf }}$ & Fraction of nutrient resorption before leaf shedding & 0.5 & - & 50 & This study \\
\hline$k_{C A}$ & Scaling parameter in crown area to diameter relationship & 100.0 & - & 51 & Sitch et al. (2003) \\
\hline$k_{r p}$ & Scaling exponent in crown area to diameter relationship & 1.6 & - & 51 & Sitch et al. (2003) \\
\hline$C A_{\max }$ & Maximum crown area & 15.0 & $m^{2}$ & 51 & Sitch et al. (2003) \\
\hline$k_{f p c}$ & Light-extinction coefficient & 0.5 & - & 52 & Sitch et al. (2003) \\
\hline$\lambda_{\text {est }}^{T}$ & Shape parameter for temperature effect on establishment & 0.075 & - & Sect. 3.10 & This study \\
\hline$k_{\text {est }}^{T}$ & Shape parameter for temperature effect on establishment & 4.0 & - & Sect. 3.10 & This study \\
\hline$\lambda_{e s t}^{\Theta_{1}}$ & Shape parameter for moisture effect on establishment & 10.0 & - & Sect. 3.10 & This study \\
\hline$k_{e s t}^{\Theta_{1}}$ & Shape parameter for moisture effect on establishment & 2.0 & - & Sect. 3.10 & This study \\
\hline
\end{tabular}


Table 4. Soil biogeochemistry parameters

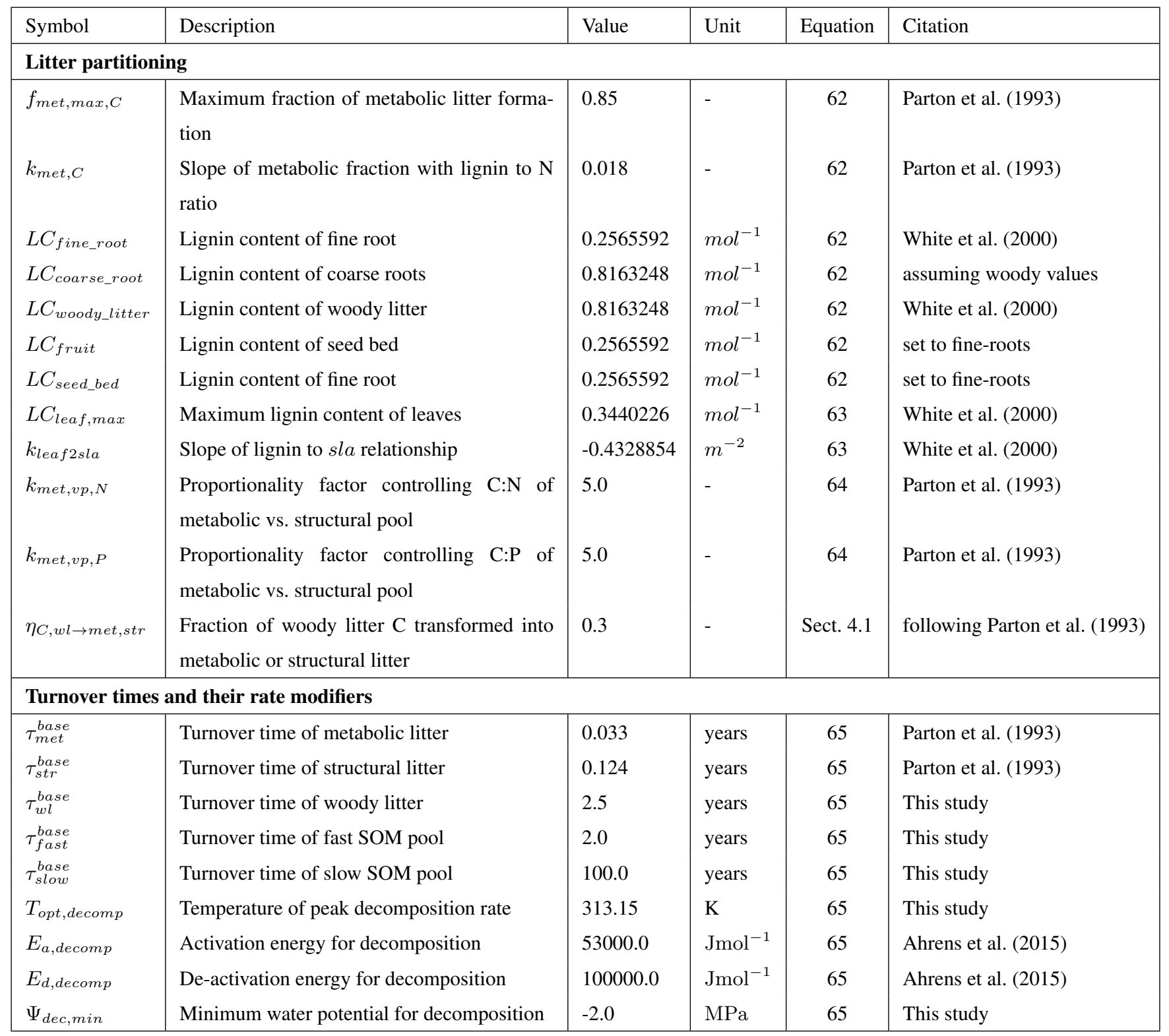


Table 4. Soil biogeochemistry parameters (ctnd.)

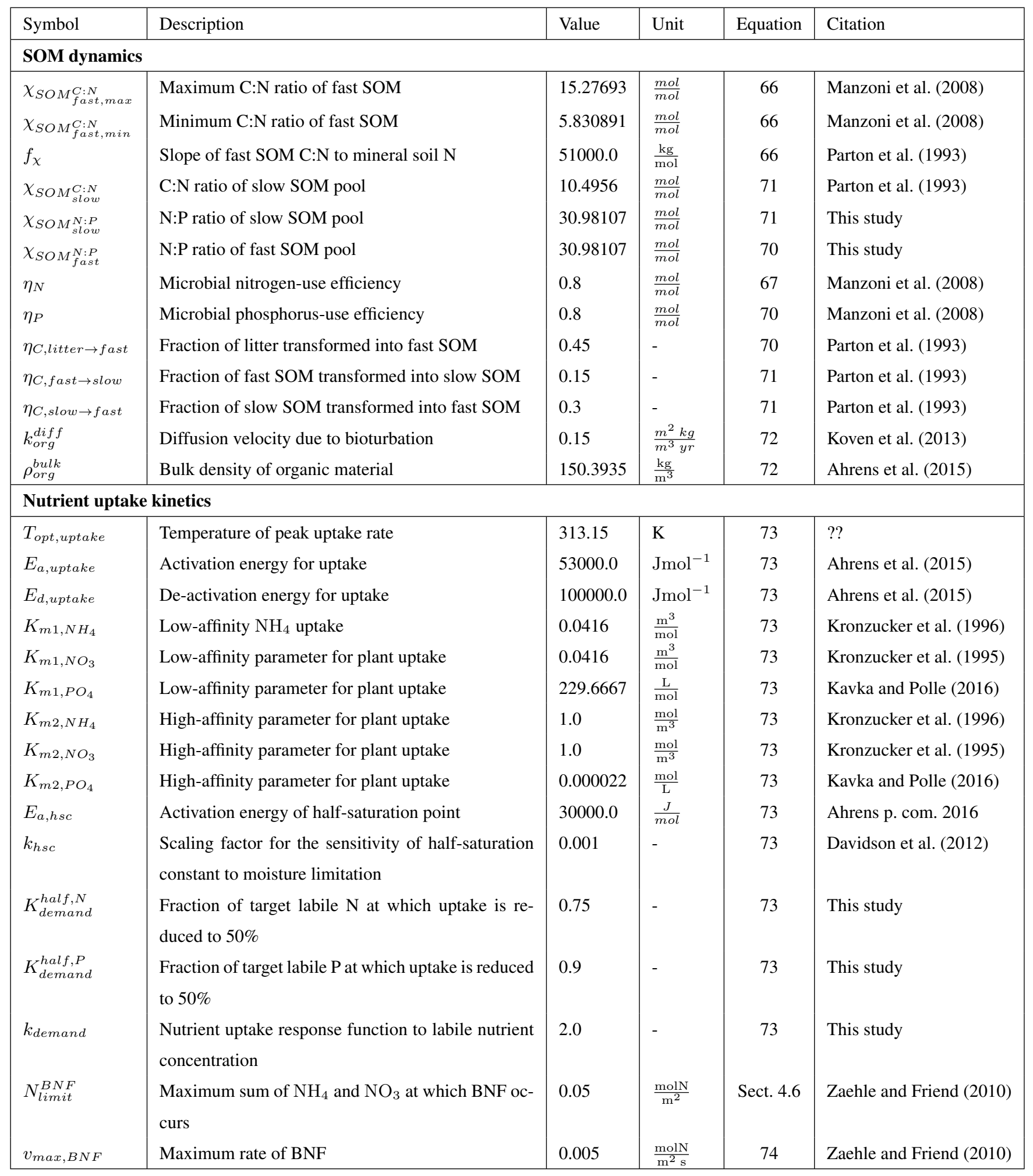


Table 4. Soil biogeochemistry parameters (ctnd.)

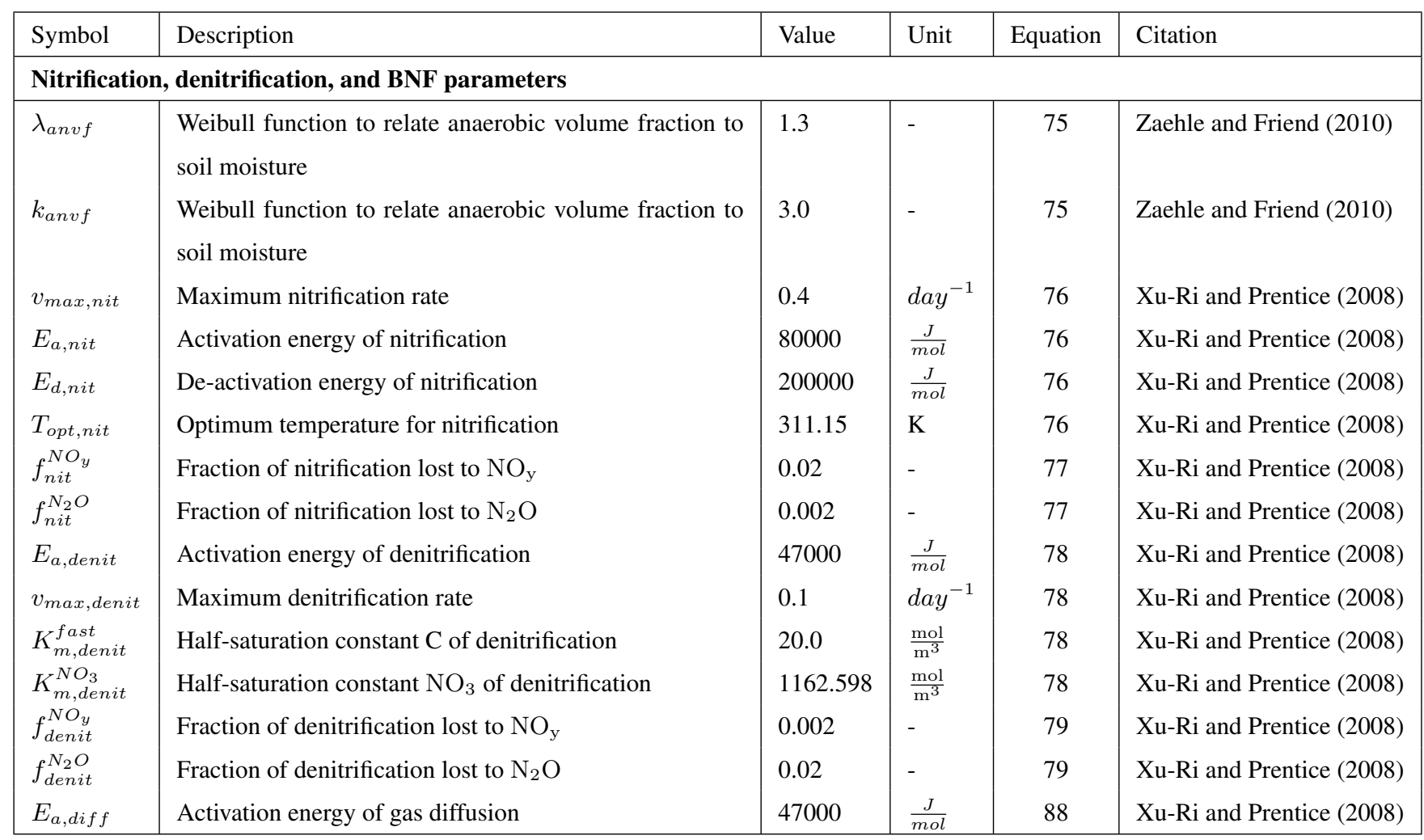


Table 4. Soil biogeochemistry parameters (ctnd.)

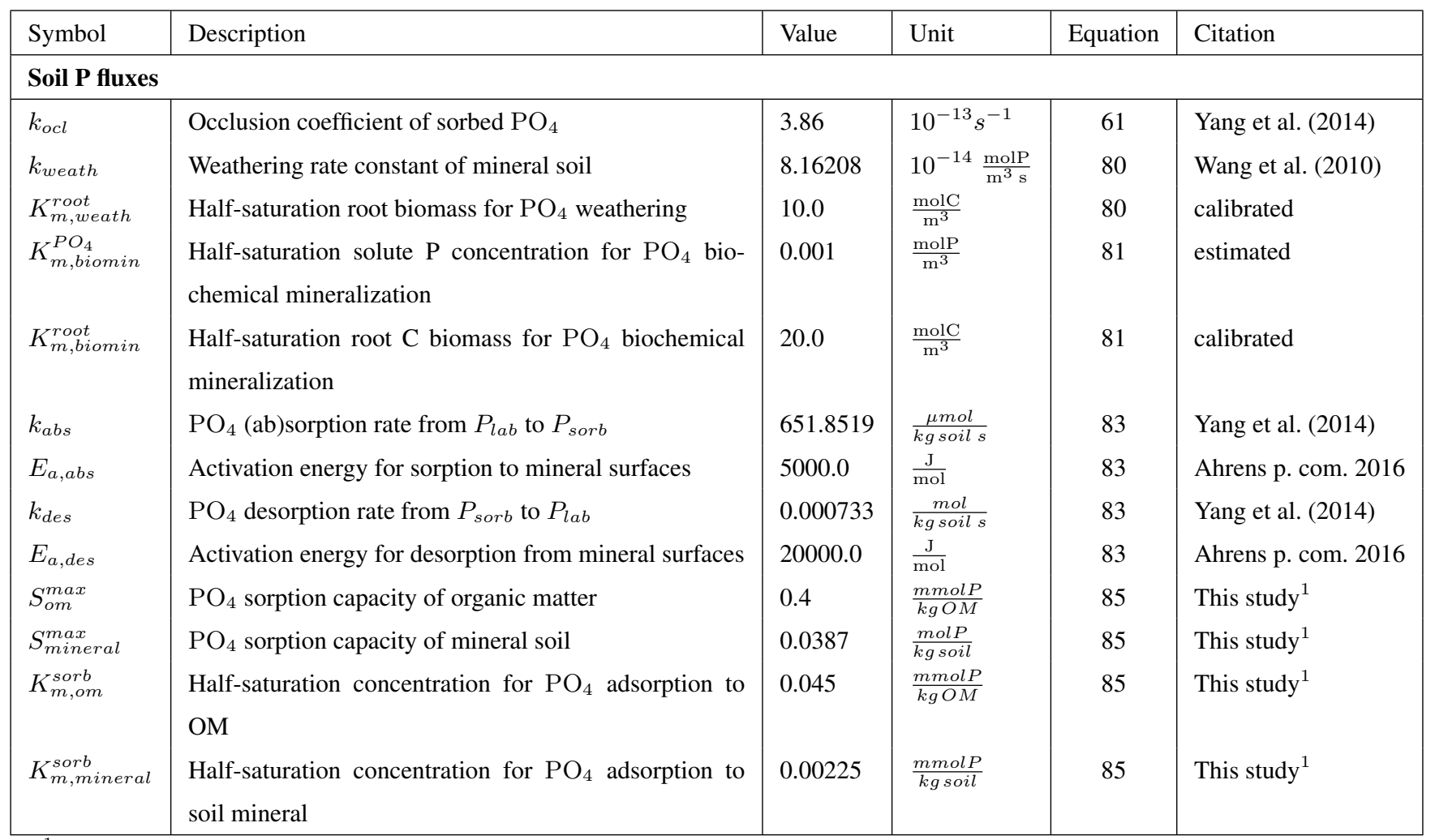

${ }^{1}$ : Based on a literature review including Abekoe and Sahrawat (2001); Ahmed et al. (2008); Chakraborty et al. (2012); Debicka et al. (2015); Dossa et al. (2008); Fan et al. (2014); Guedes et al. (2016); Harrell and Wang (2006); Hartono et al. (2005); Herlihy and McCarthy (2006); Holford et al. (1974); Horta et al. (2013); Huang et al. (2005); Janardhanan and Daroub (2010); Kolahchi and Jalali (2013); Olander and Vitousek (2005); Pal (2011); Sakadevan and Bavor (1998); Sanyal et al. (1993); Sato and Comerford (2005); Shirvani et al. (2010); Singh et al. (2005); Singh et al. (2006); Villapando and Graetz (2001); Wisawapipat et al. (2009); Xu et al. (2006); Zafar et al. (2016); Zhou and Li (2001); Zou et al. (2011) 
Table 5. Parameters for the calculation of isotopic fractionation and mixing ratios calculation

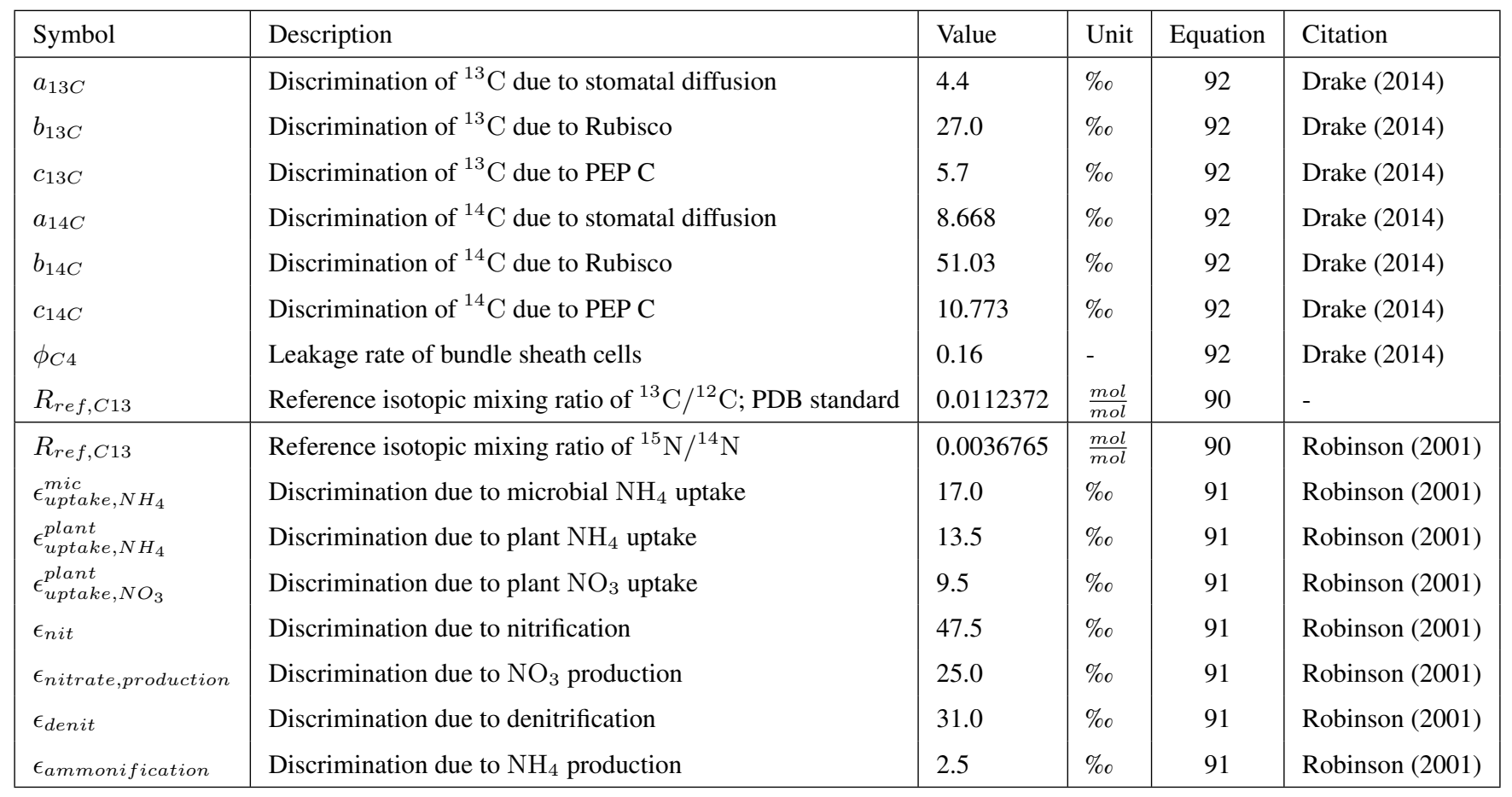

Table 6. Parameters for the albedo, fAPAR and surface energy and water calculation

\begin{tabular}{|c|c|c|c|c|c|}
\hline \multicolumn{6}{|c|}{ Albedo and fAPAR } \\
\hline$\rho^{\text {sbeta }}$ & Scaling factor of solar angle in reflection calculation & 1.6 & - & 94 & Spitters (1986) \\
\hline$k_{b l, 0}^{v i s}$ & Extinction coefficient over black leaves (VIS range) & 0.5 & - & 95 & Spitters (1986) \\
\hline$k_{d f, 0}^{v i s}$ & Extinction coefficient for diffuse radiation (VIS range) & 0.8 & - & 95 & Spitters (1986) \\
\hline$k_{c s f}$ & Crown shape correction parameter & 2.2 & - & 96 & (Campbell and Norman, 1998) \\
\hline alb vis & Soil albedo (VIS range) & 0.15 & - & 98 & Bonan (2015) \\
\hline alb $b_{\text {soil }}^{\text {nir }}$ & Soil albedo (NIR range) & 0.30 & - & 98 & Bonan (2015) \\
\hline \multicolumn{6}{|c|}{ Surface energy and water balance } \\
\hline$k_{\text {pref }}$ & Preferential flow fraction of infiltrating water & 0.01 & $\mathrm{~m}^{-1}$ & 114 & This study \\
\hline$k_{\text {pref,runoff }}$ & Infiltrating fraction of surface runoff & 0.95 & - & 114 & Krinner et al. (2005) \\
\hline
\end{tabular}


Table 7. PFT-specific parameters

\begin{tabular}{|c|c|c|c|c|}
\hline Symbol & Description & Unit & Equation & Citation \\
\hline$\sigma_{v i s}$ & Single leaf scattering albedo (VIS range) & - & 94 & Otto et al. (2014); Spitters (1986) \\
\hline$\sigma_{n i r}$ & Single leaf scattering albedo (NIR range) & - & 94 & Otto et al. (2014); Spitters (1986) \\
\hline$\phi_{\text {crown }}$ & Crown shape factor & - & 96 & Campbell and Norman (1998) \\
\hline sla & Specific leaf area & $\frac{\mathrm{m}^{-2}}{\mathrm{molC}}$ & - & Kattge et al. (2011) \\
\hline$\chi_{\text {leaf }, \text { min }}^{C: N}$ & Minimum foliar $\mathrm{C}: \mathrm{N}$ & $\frac{\mathrm{gC}}{\mathrm{gN}}$ & 37 & Kattge et al. (2011) \\
\hline$\chi_{\text {leaf }, \max }^{C: N}$ & Maximum foliar $\mathrm{C}: \mathrm{N}$ & $\frac{\mathrm{gC}}{\mathrm{gN}}$ & 37 & Kattge et al. (2011) \\
\hline$\chi_{l e a f}^{N: P}$ & Default foliar N:P & $\frac{\mathrm{gN}}{\mathrm{gP}}$ & Sect. 3.5 & Kattge et al. (2011) \\
\hline$\chi_{l e a f, \min }^{N: P}$ & Minimum foliar N:P & $\frac{\mathrm{gN}}{\mathrm{gP}}$ & 37 & Kattge et al. (2011) \\
\hline$f N_{\text {struc }, c l}^{\min }$ & Minimum fraction of structural foliar $\mathrm{N}$ & - & 4 & This study \\
\hline$T_{\Omega}$ & Shape parameter of $J_{\max }$ temperature response & $\mathrm{K}$ & 9 & Friend (2010) \\
\hline$g_{0}$ & Intercept of the $A_{n} g_{s}$ relationship & - & 17 & Lin et al. (2015) \\
\hline$g_{1}$ & Slope of the $A_{n} g_{s}$ relationship & - & 17 & Lin et al. (2015) \\
\hline$g_{\min }$ & Minimum stomatal conductance & $\frac{\mathrm{m}}{\mathrm{s}}$ & 17 & This study \\
\hline$\tau_{l e a f}$ & Turnover time of leaves & years & Sect. 3.9 & Kattge et al. (2011) \\
\hline$\tau_{\text {fine_root }}$ & Turnover time of fine roots & years & Sect. 3.9 & Ahrens et al. (2014) \\
\hline$\tau_{\text {coarse_root }}$ & Turnover time of coarse roots & years & Sect. 3.9 & Ahrens et al. (2014) \\
\hline$v_{\max , \mathrm{NH}_{4} \mid \mathrm{NO}_{3}}$ & Maximum plant $\mathrm{N}$ uptake rate & $\frac{\mu \mathrm{molN}}{\mathrm{molCs}}$ & 73 & Zaehle et al. (2010) \\
\hline$v_{\max , \mathrm{PO}_{4}}$ & Maximum plant $\mathrm{P}$ uptake rate & $\frac{\mu \mathrm{molP}}{\mathrm{molCs}}$ & 73 & Kavka and Polle (2016) \\
\hline
\end{tabular}


Table 7. PFT-specific parameters (ctnd.)

\begin{tabular}{|c|c|c|c|c|}
\hline Symbol & Description & Unit & Equation & Citation \\
\hline$G D D_{r e q}^{\max }$ & $\begin{array}{l}\text { Maximum GDD requirement in the absence of chill- } \\
\text { ing }\end{array}$ & ${ }^{\circ} \mathrm{C}$ days & 45 & This study \\
\hline$k_{\text {dormance }}^{G D D}$ & Response of GDD to number of dormant days & days $^{-1}$ & 45 & This study \\
\hline$\beta_{\text {soil }}^{\text {flush }}$ & Soil water level inducing leaf flushing & - & Sect. 3.8 & This study \\
\hline$\beta_{\text {soil }}^{\text {sen }}$ & Soil water stress inducing leaf senescence & - & Sect. 3.8 & This study \\
\hline$t_{a i r}^{s e n}$ & Air temperature threshold inducing leaf senescence & ${ }^{\circ} \mathrm{C}$ & Sect. 3.8 & This study \\
\hline$a g e_{\min }^{\text {leaf }}$ & Minimum leaf age before senescence & days & Sect. 3.8 & This study \\
\hline$f_{\text {sap_wood }}^{\text {branch }}$ & Fraction of sapwood in branches & - & Sect. 4.2 & This study \\
\hline$\rho_{w o o d}$ & Wood density & $\frac{\mathrm{gC}}{\mathrm{cm}^{3}}$ & 33 & Chave et al. (2009); Zanne et al. (2009) \\
\hline$k_{\text {latosa }}$ & Leaf area to sapwood area ratio & - & 33 & Zaehle et al. (2010) \\
\hline$k_{\text {ctos }}$ & Coarse root to sapwood mass ratio & - & 35 & This study \\
\hline$k_{r t o s}$ & $\begin{array}{l}\text { Trade-off parameter for hydraulic investment into } \\
\text { sapwood or fine roots }\end{array}$ & - & 30 & This study \\
\hline$k 2_{\text {alloc }}^{\text {fruit }}$ & Maximum fraction of growth allocated to fruit & - & 29 & This study \\
\hline$k 1_{\text {allom }}$ & Parameter in height diameter relationship & - & 34 & Zaehle et al. (2010) \\
\hline$k 2_{\text {allom }}$ & Parameter in height diameter relationship & - & 34 & Zaehle et al. (2010) \\
\hline$\Psi_{\text {leaf }}^{\min }$ & Minimum leaf water potential & $\mathrm{MPa}$ & 18 & Hickler et al. (2006) \\
\hline$k_{\text {reserve }}^{\text {target }}$ & Target size of the long-term reserve pool & - & 39 & This study \\
\hline$k_{\text {root_dist }}$ & Exponent describing the vertical root profile & - & 3 & Jackson et al. (1996) \\
\hline$k_{\text {seed }}$ & Seed size & molC & 58 & This study \\
\hline mort $_{b g, P F T}$ & Background mortality rate & year $^{-1}$ & 56 & Sitch et al. (2003) \\
\hline
\end{tabular}


Table 8. PFT-specific parameter values

\begin{tabular}{|c|c|c|c|c|c|c|c|c|}
\hline Parameter & $\operatorname{TrBE}$ & TeBE & TrBR & TeBS & BNE & BNS & $\mathrm{TeH}$ & $\mathrm{TrH}$ \\
\hline$\sigma_{v i s}$ & 0.17 & 0.17 & 0.17 & 0.17 & 0.15 & 0.15 & 0.2 & 0.2 \\
\hline$\sigma_{n i r}$ & 0.76 & 0.76 & 0.76 & 0.76 & 0.73 & 0.73 & 0.8 & 0.8 \\
\hline$\Omega_{0}$ & 0.9 & 0.9 & 0.9 & 0.9 & 0.5 & 0.7 & 1.0 & 1.0 \\
\hline$\chi_{\text {leaf }}^{C: N}$ & 28.4 & 35.0 & 22.5 & 22.5 & 39.7 & 24.8 & 26.9 & 33.9 \\
\hline$\chi_{\text {leaf }, \text { min }}^{C: N}$ & 14.0 & 14.0 & 14.0 & 14.0 & 24.0 & 16.0 & 13.7 & 17.1 \\
\hline$\chi_{\text {leaf }, \max }^{C: N}$ & 38.7 & 38.7 & 38.7 & 38.7 & 64.9 & 31.0 & 40.0 & 48.0 \\
\hline$\chi_{\text {leaf }}^{N: P}$ & 16.8 & 14.0 & 12.7 & 12.7 & 8.4 & 9.1 & 10.7 & 8.9 \\
\hline$k_{0}^{s t r u c}$ & 0.75 & 0.70 & 0.63 & 0.63 & 0.83 & 0.79 & 0.3 & 0.3 \\
\hline$f N_{\text {struc,cl }}^{\min }$ & 0.57 & 0.52 & 0.45 & 0.45 & 0.65 & 0.61 & 0.12 & 0.12 \\
\hline$T_{\Omega}$ & 18.0 & 18.0 & 18.0 & 18.0 & 18.0 & 18.0 & 18.0 & 18.0 \\
\hline$g_{0}$ & 0.01 & 0.01 & 0.01 & 0.01 & 0.01 & 0.01 & 0.03 & 0.03 \\
\hline$g_{1}$ & 9.3 & 8.3 & 7.0 & 10.9 & 5.5 & 7.0 & 9.3 & 2.0 \\
\hline$g_{\min }$ & 0.00006 & 0.00006 & 0.00006 & 0.00006 & 0.00003 & 0.00003 & 0.00006 & 0.00006 \\
\hline$\tau_{\text {leaf }}$ & 1.4 & 1.32 & 0.48 & 0.48 & 3.31 & 0.51 & 0.32 & 0.32 \\
\hline$\tau_{\text {fine_root }}$ & 0.7 & 0.7 & 0.7 & 0.7 & 0.7 & 0.7 & 0.7 & 0.7 \\
\hline$\tau_{\text {seed_est }}$ & 20.0 & 20.0 & 20.0 & 20.0 & 20.0 & 20.0 & 20.0 & 20.0 \\
\hline$v_{\max , N}$ & 0.42 & 0.42 & 0.42 & 0.42 & 0.42 & 0.42 & 0.42 & 0.42 \\
\hline$v_{\max , P}$ & 0.0044 & 0.0044 & 0.0044 & 0.0044 & 0.0044 & 0.0044 & 0.0044 & 0.0044 \\
\hline
\end{tabular}


Table 8. Lctlib Parameter Values per PFT (ctnd.)

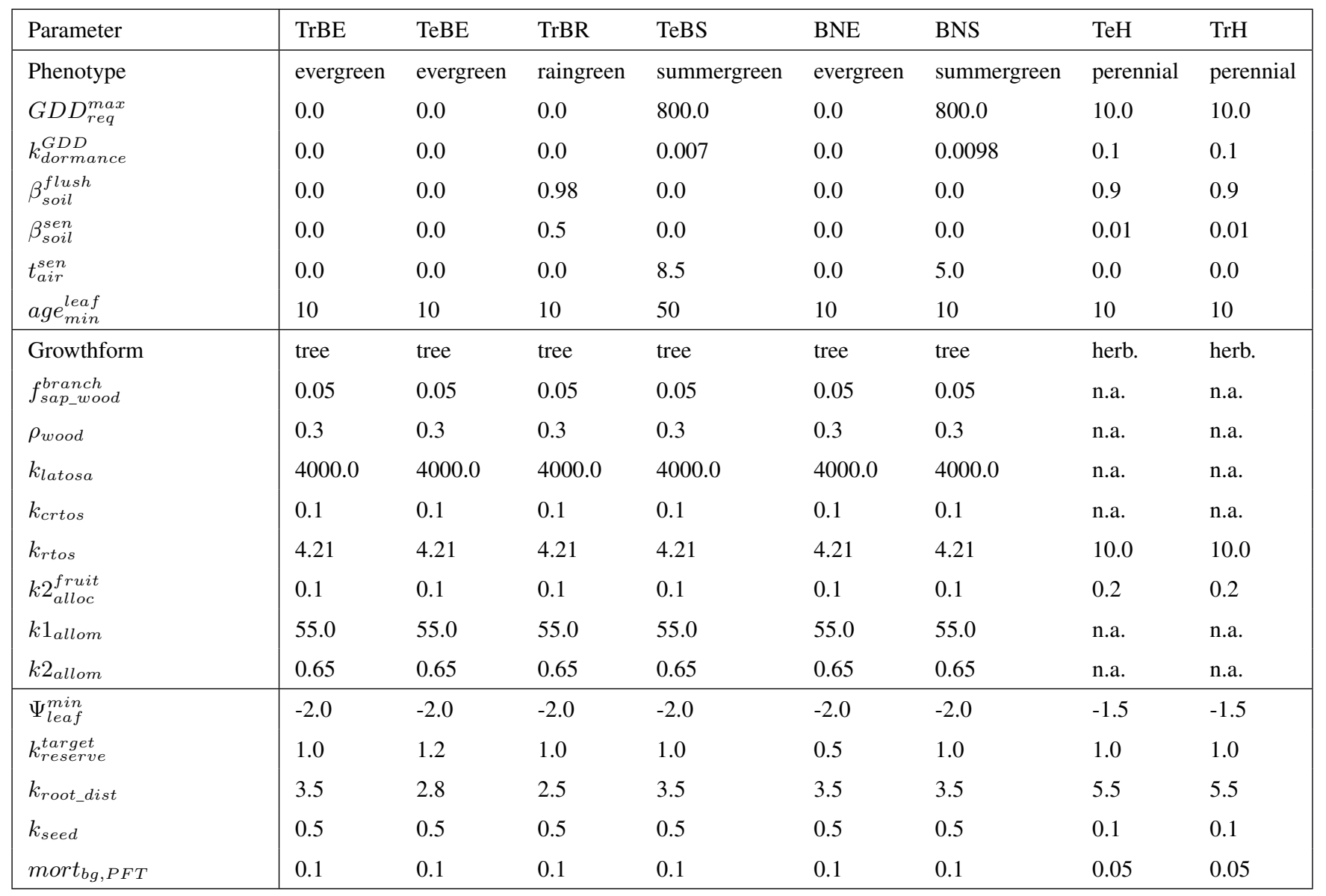




\section{References}

Abekoe, M. K. and Sahrawat, K. L.: Phosphate retention and extractability in soils of the humid zone in West Africa, Geoderma, 102, 175-187, https://doi.org/10.1016/S0016-7061(00)00110-5, http://linkinghub.elsevier.com/retrieve/pii/S0016706100001105, 2001.

Ahmed, M. F., Kennedy, I. R., Choudhury, a. T. M. a., Kecskes, M. L., and Deaker, R.: Phosphorus adsorption in some Australian soils and influence of bacteria on the desorption of phosphorus, Communications in Soil Science and Plant Analysis, 39, 1269-1294, https://doi.org/10.1080/00103620802003963, http://www.tandfonline.com/doi/abs/10.1080/00103620802003963, 2008.

Ahrens, B., Hansson, K., Solly, E. F., and Schrumpf, M.: Reconcilable differences: a joint calibration of fine-root turnover times with radiocarbon and minirhizotrons, New Phytologist, 204, 932-942, 2014.

Ahrens, B., Braakhekke, M. C., Guggenberger, G., Schrumpf, M., and Reichstein, M.: Contribution of sorption, DOC transport and microbial interactions to the $14 \mathrm{C}$ age of a soil organic carbon profile: Insights from a calibrated process model, Soil Biology and Biochemistry, 88 , 390-402, 2015.

Atkin, O. K., Meir, P., and Turnbull, M. H.: Improving representation of leaf respiration in large-scale predictive climate-vegetation models, New Phytologist, 202, 743-748, https://doi.org/10.1111/nph.12686, https://nph.onlinelibrary.wiley.com/doi/abs/10.1111/nph.12686, 2014.

Ball, J., Wooddrow, I., and Berry, J. A.: A model predicting stomatal conductance and its contribution to the control of photosynthesis under different environmental conditions, in: Progress in Photosynthesis Research, edited by Biggens, J., pp. 1-4, Dordrecht, The Netherlands, 1987.

Barrow, N. J.: The description of phosphate adsorption curves, Journal of Soil Science, 29, 447-462, 1978.

Bernacchi, C. J., Singsaas, E. L., Pimentel, C., Protis JR, A. R., and Long, S. P.: Improved temperature response functions for models of Rubisco-limited photosynthesis, Plant, Cell \& Environment, 24, 253-259, 2001.

Bonan, G.: Ecological Climatology: Concepts and Applications, Cambridge University Press, 3 edn., https://doi.org/10.1017/CBO9781107339200, 2015.

Brüggemann, N., Gessler, A., Kayler, Z., Keel, S. G., Badeck, F., Barthel, M., Boeckx, P., Buchmann, N., Brugnoli, E., Esperschütz, J., Gavrichkova, O., Ghashghaie, J., Gomez-Casanovas, N., Keitel, C., Knohl, A., Kuptz, D., Palacio, S., Salmon, Y., Uchida, Y., and Bahn, M.: Carbon allocation and carbon isotope fluxes in the plant-soil-atmosphere continuum: a review, Biogeosciences, 8, 3457-3489, 2011.

Campbell, G. S. and Norman, J. M.: An Introduction to Environmental Biophysics, Springer, 1998.

Chakraborty, D., Nair, V. D., and Harris, W. G.: Compositional Differences Between Alaquods and Paleudults Affecting Phosphorus SorptionDesorption Behavior, Soil Science, 177, 188-197, https://doi.org/10.1097/SS.0b013e31824329ca, http://content.wkhealth.com/linkback/ openurl?sid=WKPTLP:landingpage \&an=00010694-201203000-00006, 2012.

Chave, J., Coomes, D., Jansen, S., Lewis, S. L., Swenson, N. G., and Zanne, A. E.: Towards a worldwide wood economics spectrum, Ecology letters, 12, 351-366, https://doi.org/10.1111/j.1461-0248.2009.01285.x, http://dx.doi.org/10.1111/j.1461-0248.2009.01285.x, 2009.

Collatz, G. J., Ribas-Carbo, M., and Berry, J. A.: Coupled photosynthesis-stomatal conductance model for leaves of C4 plants, Australian Journal of Plant Physiology, 19, 519-538, 1992.

Davidson, E. A., Samanta, S., Caramori, S. S., and Savage, K.: The Dual Arrhenius and Michaelis-Menten kinetics model for decomposition of soil organic matter at hourly to seasonal time scales, Glob. Change Biol., 18, 371-384, 2012.

35 Debicka, M., Kocowicz, A., Weber, J., and Jamroz, E.: Organic matter effects on phosphorus sorption in sandy soils, Archives of Agronomy and Soil Science, 62, 840-855, https://doi.org/10.1080/03650340.2015.1083981, 2015. 
Dossa, E. L., Baham, J., Khouma, M., Sene, M., Kizito, F., and Dick, R. P.: Phosphorus Sorption and Desorption in Semiarid Soils of Senegal Amended With Native Shrub Residues, Soil Science, 173, 669-682, https://doi.org/10.1097/SS.0b013e3181893999, http: //content.wkhealth.com/linkback/openurl?sid=WKPTLP:landingpage\&an=00010694-200810000-00001, 2008.

Drake, B. L.: Using Models of Carbon Isotope Fractionation during Photosynthesis to Understand the Natural Fractionation Ratio, Radiocarbon, 56, 29-38, 2014.

5 Evans, J. R.: Photosynthesis and nitrogen relationships in leaves of C3 plants, Oecologia, 78, 9-19, 1989.

Fan, H., Huang, D., Zhou, L., and Jia, Y.: Effects of freeze-thaw cycles on phosphorus adsorption and desorption in the black soil of northeastern China, Acta Agriculturae Scandinavica, Section B — Soil \& Plant Science, 64, 24-32, https://doi.org/10.1080/09064710.2014.882401, 2014.

Farquhar, G. D., OLeary, M. H., and Berry, J. A.: On the Relationship Between Carbon Isotope Discrimination and the Intercellular Carbon Dioxide Concentration in Leaves, Functional Plant Biology, 9, 121-137, 1982.

Friend, A. D.: Modelling canopy CO2 fluxes: are 'big-leaf'simplifications justified?, Global ecology and biogeography: a journal of macroecology, 10, 603-619, https://nph.onlinelibrary.wiley.com/doi/abs/10.1046/j.1466-822x.2001.00268.x, 2001.

Friend, A. D.: Terrestrial plant production and climate change, Journal of Experimental Botany, 61, 1293-1309, 2010.

Friend, A. D., Stevens, A. K., Knox, R. G., and Cannell, M. G. R.: A process-based, terrestrial biosphere model of ecosystem dynamics (Hybrid v3.0), Ecological modelling, 95, 249-287, 1997.

Friend, A. D., Geider, R. J., Behrenfeld, M. J., and Still, C. J.: Photosynthesis in Global-Scale Models, in: Photosynthesis in silico: Understanding complexity from molecules to ecosystems, edited by Laisk, A., Nedbal, L., and Govindjee, pp. 465-497, Springer, 2009.

Guedes, R. S., Melo, L. C. A., Vergütz, L., Rodríguez-Vila, A., Covelo, E. F., and Fernandes, A. R.: Adsorption and desorption kinetics and phosphorus hysteresis in highly weathered soil by stirred flow chamber experiments, Soil and Tillage Research, 162, 46-54, https://doi.org/10.1016/j.still.2016.04.018, 2016.

Harrell, D. L. and Wang, J. J.: Fractionation and Sorption of Inorganic Phosphorus in Louisiana Calcareous Soils, Soil Science, 171, 3951, https://doi.org/10.1097/01.ss.0000187347.37825.46, http://content.wkhealth.com/linkback/openurl?sid=WKPTLP:landingpage\&an= 00010694-200601000-00006, 2006.

Hartono, A., Funakawa, S., and Kosaki, T.: Phosphorus sorption-desorption characteristics of selected acid upland soils in Indonesia, Soil Science and Plant Nutrition, 51, 787-799, https://doi.org/10.1111/j.1747-0765.2005.tb00113.x, http://www.tandfonline.com/doi/abs/10. 1111/j.1747-0765.2005.tb00113.x, 2005.

Herlihy, M. and McCarthy, J.: Association of soil-test phosphorus with phosphorus fractions and adsorption characteristics, Nutrient Cycling in Agroecosystems, 75, 79-90, https://doi.org/10.1007/s10705-006-9013-2, http://link.springer.com/10.1007/s10705-006-9013-2, 2006.

Hickler, T., Prentice, I. C., Smith, B., SYKES, M. T., and Zaehle, S.: Implementing plant hydraulic architecture within the LPJ Dynamic Global Vegetation Model, Global Ecology and Biogeography, 15, 567-577, 2006.

Holford, i. C. R., Wedderburn, r. W. M., and Mattingly, g. E. G.: A langmuir two-surface equation as a model for phosphate adsorption by soils, Journal of Soil Science, 25, 242-255, https://doi.org/doi:10.1111/j.1365-2389.1974.tb01121.x, https://onlinelibrary.wiley.com/doi/ abs/10.1111/j.1365-2389.1974.tb01121.x, 1974.

Horta, C., Monteiro, F., Madeira, M., and Torrent, J.: Phosphorus sorption and desorption properties of soils developed on basic rocks under a subhumid Mediterranean climate, Soil Use and Management, 29, 15-23, https://doi.org/10.1111/j.1475-2743.2012.00405.x, 2013. 
Huang, Q., Liang, W., and Cai, P.: Adsorption, desorption and activities of acid phosphatase on various colloidal particles from an Ultisol, Colloids and surfaces B: Biointerfaces, 45, 209-214, https://doi.org/10.1016/j.colsurfb.2005.08.011, http://www.ncbi.nlm.nih.gov/ pubmed/16198547, 2005.

Jackson, R. B., Canadell, J., Ehleringer, J. R., Mooney, H. A., Sala, O. E., and Schulze, E. D.: A global analysis of root distributions for terrestrial biomes, Oecologia, 108, 389-411, 1996.

5 Janardhanan, L. and Daroub, S. H.: Phosphorus Sorption in Organic Soils in South Florida, Soil Science Society of America Journal, 74, 1597-1597, https://doi.org/10.2136/sssaj2009.0137, https://www.soils.org/publications/sssaj/abstracts/74/5/1597, 2010.

June, T., Evans, J. R., and Farquhar, G. D.: A simple new equation for the reversible temperature dependence of photosynthetic electron transport: a study on soybean leaf, Functional Plant Biology, 31, 275, 2004.

Kattge, J., Díaz, S., Lavorel, S., Prentice, I. C., Leadley, P., Bönisch, G., Garnier, E., Westoby, M., Reich, P. B., Wright, I. J., Cornelissen, J. H. C., Violle, C., Harrison, S. P., Van Bodegom, P. M., Reichstein, M., Enquist, B. J., Soudzilovskaia, N. A., Ackerly, D. D., Anand, M., Atkin, O., Bahn, M., Baker, T. R., Baldocchi, D., Bekker, R., Blanco, C. C., Blonder, B., Bond, W. J., Bradstock, R., Bunker, D. E., Casanoves, F., Caverner-Bares, J., Chambers, J. Q., Chapin III, F. S., Chave, J., Coomes, D., Cornwell, W. K., Craine, J. M., Dobrin, B. H., Duarte, L., Durka, W., Elser, J., Esser, G., Estiarte, M., Fagan, W. F., Fand, J., Fernández-Méndez, F., Fidelis, A., Finegan, B., Flores, O., Ford, H., Frank, D., Freschet, G. T., Fyllas, N. M., Gallagher, R. V., Green, W. A., Gutierrez, A. G., Thomas, H., Higgins, S. I., Hodgson, J. G., Jalili, A., Jansen, S., Joly, C. A., Kerkhoff, A. J., Kirkup, D., Kitajima, K., Kleyer, M., Klotz, S., Knops, J. M. H., Kramer, K., Kühn, I., Kurokawa, H., Laughlin, D., Lee, T. D., Leishman, M., Lens, F., Lenz, T., Lewis, S. L., Lloyd, J., Llusià, J., Louault, F., Ma, S., Mahecha, M. D., Manning, P., Massad, T., Medlyn, B. E., Messier, J., Moles, A. T., Müller, S. C., Nadrowski, K., Naeem, S., Niinemets, Ü., Nöllert, S., Nüske, A., Ogaya, R., Oleksyn, J., Onipchenko, V. G., Onoda, Y., Ordoñez, J., Overbeck, G., Ozinga, W. A., Patino, S., Paula, S., Pausas, J. G., Peñuelas, J., Phillips, O. L., Pillar, V., Poorter, H., Poorter, L., Poschlod, P., Prinzing, A., Proulx, R., Rammig, A., Reinsch, S., Reu, B., Sack, L., Salgado-Negret, B., Sardans, J., Shiodera, S., Shipley, B., Siefert, A., Sosinski, E., Soussana, J. F., Swaine, E., Swenson, N., Thompson, K., Thornton, P., Waldram, M., Weiher, E., White, M., White, S., Wright, S. J., Yguel, B., Zaehle, S., Zanne, A. E., and Wirth, C.: TRY - a global database of plant traits, Global Change Biology, 17, 2905-2935, 2011.

Kavka, M. and Polle, A.: Phosphate uptake kinetics and tissue-specific transporter expression profiles in poplar (Populus $\times$ canescens) at different phosphorus availabilities, BMC Plant Biology, 16, 206, https://doi.org/10.1186/s12870-016-0892-3, https://doi.org/10.1186/ s12870-016-0892-3, 2016

Knauer, J., Werner, C., and Zaehle, S.: Evaluating stomatal models and their atmospheric drought response in a land surface scheme: A multibiome analysis, Journal of Geophysical Research: Biogeosciences, 120, 1894-1911, 2015.

Kolahchi, Z. and Jalali, M.: Phosphorus Movement and Retention by Two Calcareous Soils, Soil and Sediment Contamination: An International Journal, 22, 21-38, https://doi.org/10.1080/15320383.2012.697939, 2013.

30 Koven, C. D., Riley, W. J., Subin, Z. M., Tang, J. Y., Torn, M. S., Collins, W. D., Bonan, G. B., Lawrence, D. M., and Swenson, S. C.: The effect of vertically resolved soil biogeochemistry and alternate soil $\mathrm{C}$ and $\mathrm{N}$ models on C dynamics of CLM4, Biogeosciences, 10, 7109-7131, 2013.

Krinner, G., Viovy, N., de Noblet-Ducoudré, N., Ogée, J., Polcher, J., Friedlingstein, P., Ciais, P., Sitch, S. A., and Prentice, I. C.: A dynamic global vegetation model for studies of the coupled atmosphere-biosphere system, Global Biogeochemical Cycles, 19, GB1015, 2005.

Kronzucker, H. J., Siddiqi, M. Y., and Glass, A. D. M.: Kinetics Of NO3-Influx In Spruce, Plant Physiology, 109, 319-326, 1995.

Kronzucker, H. J., Siddiqi, M. Y., and Glass, A. D. M.: Kinetics of NH4+ influx in spruce, Plant Physiology, 110, 773-779, 1996. 
Kull, O. and Kruijt, B.: Leaf photosynthetic light response: a mechanistic model for scaling photosynthesis to leaves and canopies, Functional Ecology, 12, 767-777, 1998.

Levin, I., Naegler, T., Kromer, B., Diehl, M., Francey, R., Gomez-Pelaez, A., Steele, P., Wagenbach, D., Weller, R., and Worthy, D.: Observations and modelling of the global distribution and long-term trend of atmospheric ${ }^{14} \mathrm{CO}_{2}$, Tellus Series B-Chemical and Physical Meteorology, 62, 26-46, 2010.

5 Lin, Y.-S., Medlyn, B. E., Duursma, R. A., Prentice, I. C., Wang, H., Baig, S., Eamus, D., de Dios, V. R., Mitchell, P., Ellsworth, D. S., de Beeck, M. O., Wallin, G., Uddling, J., Tarvainen, L., Linderson, M.-L., Cernusak, L. A., Nippert, J. B., Ocheltree, T. W., Tissue, D. T., Martin-StPaul, N. K., Rogers, A., Warren, J. M., De Angelis, P., Hikosaka, K., Han, Q., Onoda, Y., Gimeno, T. E., Barton, C. V. M., Bennie, J., Bonal, D., Bosc, A., Low, M., Macinins-Ng, C., Rey, A., Rowland, L., Setterfield, S. A., Tausz-Posch, S., Zaragoza-Castells, J., Broadmeadow, M. S. J., Drake, J. E., Freeman, M., Ghannoum, O., Hutley, L. B., Kelly, J. W., Kikuzawa, K., Kolari, P., Koyama, K., Limousin, J. M., Meir, P., Lola da Costa, A. C., Mikkelsen, T. N., Salinas, N., Sun, W., and Wingate, L.: Optimal stomatal behaviour around the world, Nature Climate Change, 5, 459-464, 2015.

Lloyd, J. and Taylor, J. A.: On the temperature dependence of soil respiration, Functional ecology, pp. 315-323, https://www.jstor.org/stable/ 2389824, 1994.

Makino, A., Sakuma, H., Sudo, E., and Mae, T.: Differences between maize and rice in N-use efficiency for photosynthesis and protein allocation, Plant \& cell physiology, 44, 952-956, https://www.ncbi.nlm.nih.gov/pubmed/14519777, 2003.

Manzoni, S., Porporato, A., and Schimel, J. P.: Soil heterogeneity in lumped mineralization-immobilization models, Soil Biology and Biochemistry, 40, 1137-1148, 2008.

McGill, W. B. and Cole, C. V.: Comparative aspects of cycling of organic C, N, S and P through soil organic matter, Geoderma, 26, 267-286, 1981.

20 Meyerholt, J. and Zaehle, S.: The role of stoichiometric flexibility in modelling forest ecosystem responses to nitrogen fertilization, New Phytologist, pp. n/a-n/a, 2015.

Monteith, J. L. and Unsworth, M. H.: Principles of Environmental Physics (Fourth Edition), Academic Press, Boston, fourth edition edn., https://doi.org/https://doi.org/10.1016/B978-0-12-386910-4.00023-8, http://www.sciencedirect.com/science/article/ pii/B9780123869104000238, 2013.

25 Mäkelä, A., Hari, P., Berninger, F., Hänninen, H., and Nikinmaa, E.: Acclimation of photosynthetic capacity in Scots pine to the annual cycle of temperature, Tree Physiology, 24, 369-376, https://doi.org/10.1093/treephys/24.4.369, http://dx.doi.org/10.1093/treephys/24.4. $369,2004$.

Niinemets, Ü. and Tenhunen, J. D.: A model separating leaf structural and physiological effects on carbon gain along light gradients for the shade-tolerant species Acer saccharum, Plant, Cell and Environment, 20, 845-866, 1997.

30 Niinemets, Ü., Kull, O., and Tenhunen, J. D.: An analysis of light effects on foliar morphology, physiology, and light interception in temperate deciduous woody species of contrasting shade tolerance, Tree Physiology, 18, 681-696, https://doi.org/10.1093/treephys/18.10.681, http: //dx.doi.org/10.1093/treephys/18.10.681, 1998.

Olander, L. P. and Vitousek, P. M.: Short-term controls over inorganic phosphorus during soil and ecosystem development, Soil Biology and Biochemistry, 37, 651-659, https://doi.org/10.1016/j.soilbio.2004.08.022, 2005.

Otto, J., Berveiller, D., Bréon, F.-M., Delpierre, N., Geppert, G., Granier, A., Jans, W., Knohl, A., Kuusk, A., Longdoz, B., and Others: Forest summer albedo is sensitive to species and thinning: how should we account for this in Earth system models?, Biogeosciences, 11, 2411-2427, https://goedoc.uni-goettingen.de/handle/1/10219, 2014. 
Pal, S. K.: Phosphorus sorption-desorption characteristics of soils under different land use patterns of eastern India, Archives of Agronomy and Soil Science, 57, 365-376, https://doi.org/10.1080/03650341003605743, http://www.tandfonline.com/doi/abs/10.1080/ $03650341003605743,2011$.

Parton, W. J., Scurlock, J. M. O., Ojima, D. S., Gilmanov, T. G., Scholes, R. J., Schimmel, D. S., Kirchner, T., Menaut, J. C., Seastedt, T., Moya, E. G., Kamnalrut, A., and Kinyamario, J. I.: Observations and modelling of biomass and soil organic matter dynamics for the grassland biome worldwide, Global Biogeochemical Cycles, 7, 785-809, 1993.

Raddatz, T. J., Reick, C. H., Knorr, W., Kattge, J., Roeckner, E., Schnur, R., Schnitzler, K.-G., Wetzel, P., and Jungclaus, J.: Will the tropical land biosphere dominate the climate-carbon cycle feedback during the twenty-first century?, Climate Dynamics, 29, 565-574, https://doi.org/10.1007/s00382-007-0247-8, https://doi.org/10.1007/s00382-007-0247-8, 2007.

Robinson, D.: $\delta 15 \mathrm{~N}$ as an integrator of the nitrogen cycle, Trends in ecology \& evolution, 16, 153-162, https://doi.org/10.1016/S01695347(00)02098-X, http://www.sciencedirect.com/science/article/pii/S016953470002098X, 2001.

Roeckner, E., Tompkins, A., Bäuml, G., Bonaventura, L., Brokopf, R., Esch, M., Giorgetta, M., Hagemann, S., Kirchner, I., Kornblueh, L., Manzini, E., Rhodin, E., Schlese, U., and Schulzweida, U.: The atmospheric general circulation model ECHAM5 - Part I: Model description, Tech. Rep. 349, Max Planck Institute for Meteorology, Hamburg, 2003.

Rogers, A., Medlyn, B. E., Dukes, J. S., Bonan, G. B., von Caemmerer, S., Dietze, M. C., Kattge, J., Leakey, A. D. B., Mercado, L. M.,

Niinemets, Ü., Prentice, I. C., Serbin, S. P., Sitch, S. A., Way, D. A., and Zaehle, S.: A roadmap for improving the representation of photosynthesis in Earth system models, New Phytologist, 213, 22-42, 2017.

Sakadevan, K. and Bavor, H. J.: Phosphate adsorption characteristics of soils, slags and zeolite to be used as substrates in constructed wetland systems, Water Research, 32, 393-399, https://doi.org/10.1016/S0043-1354(97)00271-6, 1998.

Sanyal, S. K., Chan, P. Y., and De Datta, S. K.: Phosphate Sorption-Desorption Behavior of Some Acidic Soils of South and Southeast Asia, Soil Science Society of America Journal, 57, 937-937, https://doi.org/10.2136/sssaj1993.03615995005700040011x, https://www.soils. org/publications/sssaj/abstracts/57/4/SS0570040937, 1993.

Sato, S. and Comerford, N. B.: Influence of soil pH on inorganic phosphorus sorption and desorption in a humid Brazilian Ultisol, Revista Brasileira de Ciencia do Solo, 29, 685-694, https://doi.org/10.1590/S0100-06832005000500004, 2005.

Saxton, K. E. and Rawls, W. J.: Soil Water Characteristic Estimates by Texture and Organic Matter for Hydrologic Solutions, Soil Science Society of America Journal, 70, 1569-10, 2006.

Shirvani, M., Khalili, B., Mohaghegh, P., Ghasemi, S., Arabzadegan, H., and Nourbakhsh, F.: Land-Use Conversion Effects on Phosphate Sorption Characteristics in Soils of Forest and Rangeland Sites from Zagros Area, Western Iran, Arid Land Research and Management, 24, 223-237, https://doi.org/10.1080/15324982.2010.487454, http://www.tandfonline.com/doi/abs/10.1080/15324982.2010.487454, 2010.

Singh, B. R., Krogstad, T., Shivay, Y. S., Shivakumar, B. G., and Bakkegard, M.: Phosphorus fractionation and sorption in P-enriched soils of Norway, Nutrient Cycling in Agroecosystems, 73, 245-256, https://doi.org/10.1007/s10705-005-2650-z, http://link.springer.com/10. 1007/s10705-005-2650-z, 2005.

Singh, V., Dhillon, N. S., and Brar, B. S.: Influence of long-term use of fertilizers and farmyard manure on the adsorption-desorption behaviour and bioavailability of phosphorus in soils, Nutrient Cycling in Agroecosystems, 75, 67-78, https://doi.org/10.1007/s10705006-9012-3, http://link.springer.com/10.1007/s10705-006-9012-3, 2006.

35 Sitch, S. A., Smith, B., Prentice, I. C., Arneth, A., Bondeau, A., Cramer, W., Kaplan, J. O., Levis, S., Lucht, W., Sykes, M. T., and Venevsky, S.: Evaluation of ecosystem dynamics, plant geography and terrestrial carbon cycling in the LPJ Dynamic Global Vegetation Model, Global Change Biology, 9, 161-185, 2003. 
Spitters, C. J. T.: Separating the Diffuse and Direct Component of Global Radiation and Its Implications for Modeling Canopy Photosynthesis .2. Calculation of Canopy Photosynthesis, Agricultural and Forest Meteorology, 38, 231-242, 1986.

Sprugel, D. G., Ryan, M. G., Brooks, J. R., Vogt, K. A., and Martin, T. A.: Respiration from the Organ Level to the Stand, in: Resource Physiology of Conifers, edited by Smith, W. K. and Hinckley, T. M., pp. 255-299, Academic Press, San Diego, https://doi.org/10.1016/B9780-08-092591-2.50013-3, http://www.sciencedirect.com/science/article/pii/B9780080925912500133, 1995.

5 Tazoe, Y., Noguchi, K. O., and Terachima, I.: Effects of growth light and nitrogen nutrition on the organization of the photosynthetic apparatus in leaves of a C4 plant, Amaranthus cruentus, Plant, Cell and Environment, 29, 691-700, 2006.

Villapando, R. R. and Graetz, D. a.: Phosphorus Sorption and Desorption Properties of the Spodic Horizon from Selected Florida Spodosols, Soil Science Society of America Journal, 65, 331-331, https://doi.org/10.2136/sssaj2001.652331x, 2001.

Wang, Y. P., Law, R. M., and Pak, B.: A global model of carbon, nitrogen and phosphorus cycles for the terrestrial biosphere, Biogeosciences, 7, 2261-2282, 2010.

White, M. A., Thornton, P. E., Running, S., and Nemani, R.: Parameterization and Sensitivity Analysis of the BIOME-BGC Terrestrial Ecosystem Model: Net Primary Production Controls, Earth Interactions, 4, 1-55, 2000.

Wisawapipat, W., Kheoruenromne, I., Suddhiprakarn, A., and Gilkes, R. J.: Phosphate sorption and desorption by Thai upland soils, Geoderma, 153, 408-415, https://doi.org/10.1016/j.geoderma.2009.09.005, http://linkinghub.elsevier.com/retrieve/pii/S0016706109002821, 2009.

Wullschleger, S. D.: Biochemical Limitations to Carbon Assimilation in C3 Plants-A Retrospective Analysis of the A/Ci Curves from 109 Species, Journal of experimental botany, 44, 907-920, https://doi.org/10.1093/jxb/44.5.907, https://academic.oup.com/jxb/article-abstract/ 44/5/907/503778, 1993.

$\mathrm{Xu}, \mathrm{D} ., \mathrm{Xu}, \mathrm{J} ., \mathrm{Wu}$, J., and Muhammad, A.: Studies on the phosphorus sorption capacity of substrates used in constructed wetland systems, Chemosphere, 63, 344-352, https://doi.org/10.1016/j.chemosphere.2005.08.036, http://www.ncbi.nlm.nih.gov/pubmed/16242173, 2006.

Xu-Ri and Prentice, I. C.: Terrestrial nitrogen cycle simulation with a dynamic global vegetation model, Global Change Biology, 14, 17451764, 2008.

Yang, X., Thornton, P. E., Ricciuto, D. M., and Post, W. M.: The role of phosphorus dynamics in tropical forests - a modeling study using CLM-CNP, Biogeosciences, 11, 1667-1681, https://doi.org/10.5194/bg-11-1667-2014, https://www.biogeosciences.net/11/1667/2014/, 2014.

Zaehle, S. and Friend, A. D.: Carbon and nitrogen cycle dynamics in the O-CN land surface model: 1. Model description, site-scale evaluation, and sensitivity to parameter estimates, Global Biogeochemical Cycles, 24, GB 1005, 2010.

Zaehle, S., Friedlingstein, P., and Friend, A. D.: Terrestrial nitrogen feedbacks may accelerate future climate change, Geophysical Research Letters, 37, https://doi.org/10.1029/2009GL041345, https://agupubs.onlinelibrary.wiley.com/doi/abs/10.1029/2009GL041345, 2010.

Zaehle, S., Ciais, P., Friend, A. D., and Prieur, V.: Carbon benefits of anthropogenic reactive nitrogen offset by nitrous oxide emissions, Nature Geoscience, 4, 601-605, 2011.

Zafar, M., Tiecher, T., de Castro Lima, J. A., Schaefer, G. L., Santanna, M. A., and Dos Santos, D. R.: Phosphorus seasonal sorptiondesorption kinetics in suspended sediment in response to land use and management in the Guapore catchment, Southern Brazil, Environ Monit Assess, 188, 643, https://doi.org/10.1007/s10661-016-5650-3, https://www.ncbi.nlm.nih.gov/pubmed/27796828, 2016.

Zanne, A., Lopez-Gonzalez, G., Coomes, D., Ilic, J., Jansen, S., Lewis, S., Miller, R., Swenson, N., Wiemann, M., and Chave, J.: Data from: Towards a worldwide wood economics spectrum, https://doi.org/doi:10.5061/dryad.234, https://doi.org/10.5061/dryad.234, 2009. 
Zerihun, A., McKenzie, B. A., and Morton, J. D.: Photosynthate costs associated with the utilization of different nitrogen-forms: influence on the carbon balance of plants and shoot-root biomass partitioning, The New Phytologist, 138, 1-11, 1998.

Zhou, M. and Li, Y.: Phosphorus-Sorption Characteristics of Calcareous Soils and Limestone from the Southern Everglades and Adjacent Farmlands, Soil Science Society of America Journal, 65, 1404-1404, https://doi.org/10.2136/sssaj2001.6551404x, 2001.

Zou, P., Fu, J., and Cao, Z.: Chronosequence of paddy soils and phosphorus sorption-desorption properties, Journal of Soils and Sediments, 11, 249-259, https://doi.org/10.1007/s11368-010-0301-8, http://link.springer.com/10.1007/s11368-010-0301-8, 2011. 